\title{
Ales Stones in Southern Sweden: A Remarkable Monument of the Sun Cult and Advanced Astronomy in the Bronze Age
}

\author{
Nils-Axel Mörner*, Bob G. Lind \\ Paleogeophysics \& Geodynamics, Stockholm, Sweden \\ Email: *morner@pog.nu
}

How to cite this paper: Mörner, N.-A., \& Lind, B. G. (2019). Ales Stones in Southern Sweden: A Remarkable Monument of the Sun Cult and Advanced Astronomy in the Bronze Age. Archaeological Discovery, 7, 92-126.

https://doi.org/10.4236/ad.2019.72007

Received: March 28, 2019

Accepted: April 22, 2019

Published: April 25, 2019

Copyright ( 2019 by author(s) and Scientific Research Publishing Inc. This work is licensed under the Creative Commons Attribution International License (CC BY 4.0).

http://creativecommons.org/licenses/by/4.0/

\begin{abstract}
Ales Stones is a famous stone ship in southern Sweden. Besides its size $(69 \mathrm{~m})$ and location right beside the shore of the Baltic, it is a remarkable monument of the Sun Cult and very advanced knowledge of astronomy by the Bronze Age people. This paper summarizes the findings, and puts it into the context of other monuments in southern Sweden. Also presented are a new time-correction of the sunrise at Winter solstice $700 \mathrm{BC}$ and a remarkable sun-wheel on the Island of Bornholm of astronomical dimensions almost identical to those of the Ales Stones monument: the Madsebakke Sun-wheel. It all provides a congruent picture of intensive Sun Cult activity and close connections between of southeast Sweden and the Island of Bornholm.
\end{abstract}

\section{Keywords}

Ales Stones, Astronomy, Solar Alignment, Late Bronze Age 700 BC, Stratigraphy, Sand Drift, Quarrying, Sun Cult, Rock-Carvings, Madsebakke Sun-Wheel

\section{Introduction}

Despite the fact that thousands of stone ships were built in Scandinavia in the period 1000-4000 BP, there are no traces anywhere of a stone ship comparable to Ales Stones. It is unique. The stone ship of Ales Stones is $69 \mathrm{~m}$ long and $19 \mathrm{~m}$ wide, and it is strictly aligned with respect to the sunrise at Winter solstice in the SE and the sunset at Summer solstice in the NW (Figure 1). Radiocarbon dates indicate that the stones were in position by about $500 \mathrm{AD}$, at the latest. Stratigraphy indicates that the monument was erected before the major sand-drift period dated at 600-400 BC (Mörner, 2015). Cup marks are indicative of the 
Bronze Age (1750-500 BC). Finally, the list of archaeological finds in the vicinity (Table 1) includes numerous finds from the Bronze Age, but zero finds from the Neolithic and Iron Age. Converging facts seem to indicate that Ales Stones was erected in the Bronze Age (Lind, 2004, 2005; Lind \& Mörner, 2010; Mörner, 2015).

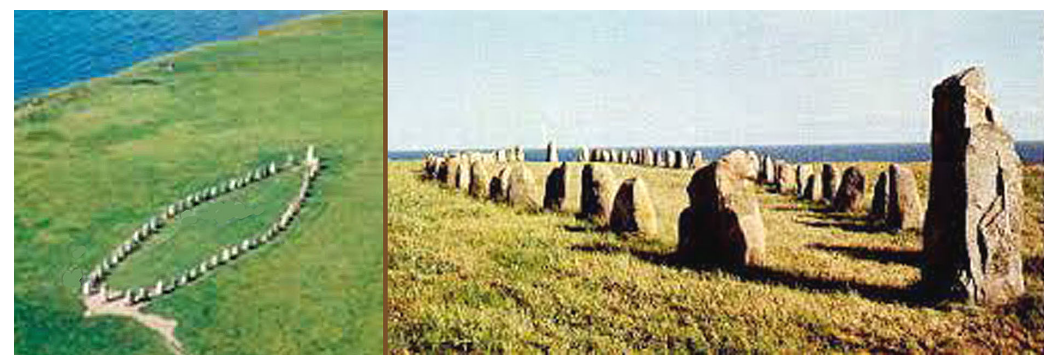

Figure 1. Ales Stones: a stone ship strictly aligned with respect to the Sun's annual and daily motions over the sky with the bow in the NW where the Sun sets at summer solstice, and the stern in the SE where the Sun rises at winter solstice.

The ship consists of 57 stones (originally 58 stones). The bow and stern stones are two monoliths of quartzite, quarried at Brantevik $20 \mathrm{~km}$ to the NE (Mörner, 2015). There is also a "rudder stone" and an "altar-stone" of quartzite. Today, the so-called "altar-stone" lies inside the ship, thrown there by the farmer from its original position in front of the bow stone. Therefore, this stone must have originally marked the ram of the ship. The ram (in its original position) and the so-called "rudder stone" are likely to represent the extended keel stern typical for ancient Greek ships and the ships found in Swedish rock carvings (Figure 2). On a drawing from 1777 (Hilfeling, 1777), the stone ship is drawn in great details (Figure 3) and there is no stone drawn where the "altar stone" is lying today.

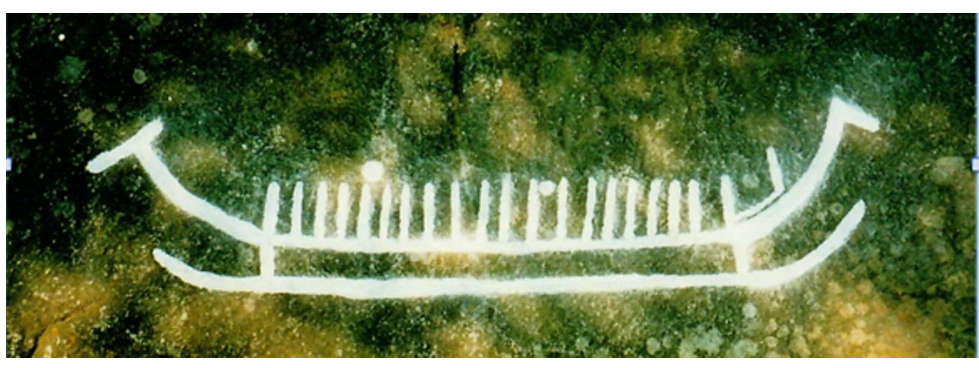

Figure 2. Ship on a rock carving from the Bronze Age (located at Simris $2 \mathrm{~km}$ north of Brantevik). The keel stern is extended into rams both in the bow and the stern of the ship.

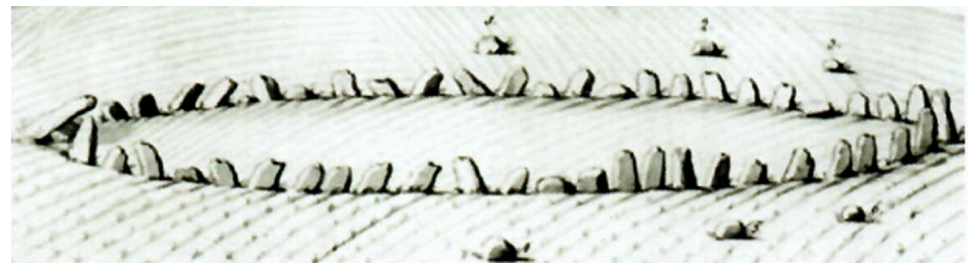

Figure 3. The drawing by Hilfeling from 1777. Note that the "altar stone" is not present inside the ship and that the stern stones are in firm positions (whilst the bow stone is tilted). 


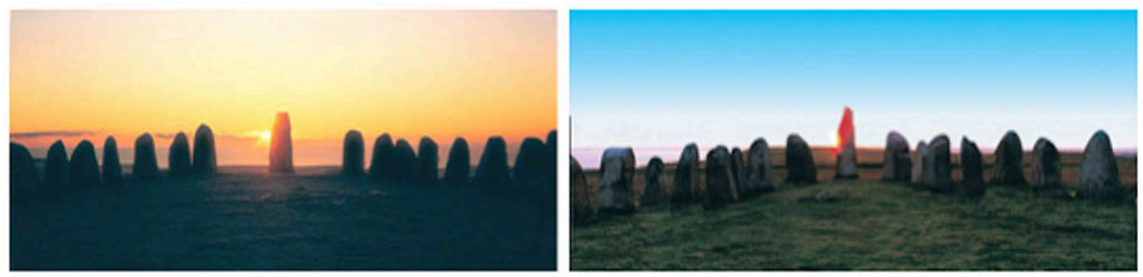

Figure 4. Ales Stones has a very strict SE-NW orientation with respect to the stern stone in the SE just where the Sun rises at Winter solstice (left) and with the bow stone in the NW just where the Sun sets at Summer solstice (right).

The strict solar alignment of the ship is illustrated in Figure 4. At Winter solstice, the Sun is rising just beside the stern stone, and at Summer solstice, it is setting right behind the bow stone. As evident from the drawing by Hilfeling (Figure 3), the stern stone was standing upright in its original position in 1777 (whilst the bow stone was half fallen). In a photography from 1916 (Lind \& Mörner, 2010), the 3 stern stones are still in original position, whilst the bow stone is lying down. This implies that strict calculations of the solar alignment can only be done with respect to the stern stone. In Figure 4, the Sun rises just to the left of the stern stone. The tiny deviation in alignment (about $15-17$ $\mathrm{cm}$ ) is a measure of the time elapsed since the erection of the stern stone (see below).

With this description of the general shape and organization of the Ales Stones magnificent stone ship, we turn to the dating and the interpretations of the function of the monument (cf. Lind, 2004; Lind \& Mörner, 2010; Mörner, 2015).

\section{Dating the Erection of the Ship}

There are five main means of shedding light on the time of the erection of the Ales Stone monument, viz. 1) the age of archeological finds in the vicinity of the ship, 2) C14-dates of finds inside the ship, 3) the exact solar alignment with respect to the sunrise at Winter solstice over the stern stone, 4) stratigraphy and C14-dates at Ales Stones, and 5) the time of the quarrying and shipping of the 4 quartzite blocks (Section 3).

\subsection{Archaeological Finds at and around Ales Stones}

Table 1 lists all the archaeological finds in the vicinity of Ales Stones. Whilst there are lots of finds of tools and objects from the Bronze Age, especially the Late Bronze Age, there are no finds at all of objects from the Neolithic and the Iron Age (except for a number of charcoal dates as listed in Table 1). This seems quite significant for the age of the activity at Ales Stones. This was also the conclusion drawn at the excavation in 2011 (Mörner, 2011; Duczko, 2011).

From the Neolithic, there are two C14-dates of charcoal. One from a hearth just in front of the bow stone of Ales Stones, collected and dated by Lind (Lind \& Mörner, 2010; Mörner, 2015). The age is $3175 \pm 375$ cal. yrs BC, which implies that humans were present in the area at least 5000 years ago. There is also a charcoal date of $2525 \pm 36$ cal. yrs BC from a depression in the old till surface 
(Andersson et al., 2013).

Table 1. List of archaeological finds and dates in the vicinity of Ales Stones (AS).

\section{Neolithic (N):}

1) Hearth in front of AS dated at $3175 \pm 375$ cal. yrs BC (a)

2) Charcoal from a depression dated at $2525 \pm 36 \mathrm{cal}$. yrs BC (a, b)

3) Some tools of flint (b)

Bronze Age (B.A.):

1) Cup marks in the form of the Swan constellation on stone 1 in the NW (Figure 7)

2) Three cup marks on stone 8 in the $W$ strictly aligned to the sunrise at winter solstice (Figure 8(a))

3) Four cup marks on stone 8 in the E strictly aligned to the annual solar motions (Figure 8(b))

4) Razor from the Late B.A. found in the 30 's $50 \mathrm{~m}$ to the E of AS (c)

5) Hollow axe from the Late B.A. found in the 30 's close to AS (c)

6) Knife of bronze from the Late B.A. found $50 \mathrm{~m}$ to the $\mathrm{E}$ of AS (c)

7) Neck ring of bronze from the Late B.A. found in $193740 \mathrm{~m}$ to the E of AS (c)

8) Eight arrow points of bronze from the Late B.A. found in $193715-20 \mathrm{~m}$ to the $\mathrm{S}$ of AS (e)

9) Bronze dagger, $30 \mathrm{~cm}$ long, from the Late B.A. found in $193710 \mathrm{~m}$ from AS (e)

10) Loop button of bronze from the Late B.A. found in 1988 close to AS (c)

11) Stone in the form of a foot with cup marks found in $199410 \mathrm{~m}$ from AS (e)

12) Amber owl found in $195340 \mathrm{~m}$ E of AS (e)

13) Eleven pieces of flint found in 2011 (in excavation pit $\mathrm{E}$ ) $30 \mathrm{~m}$ from AS ( $\mathrm{f}$ )

14) Imprint of removed block $(1.0 \times 2.5 \mathrm{~m})$ covered by eolian sand dated at $600 \mathrm{cal}$. yrs BC (f)

15) Charcoal in shore cliff dated at $785 \pm 20$ and $775 \pm 35$ cal. yrs BC (a)

Iron Age (I.A.):

1) Hearth in the shore cliff dated at $385 \pm 35$ cal. yrs BC (a)

2) Urn buried in eolian sand in the ship dated at $400 \pm 150$ and $525 \pm 105$ cal. yrs AD (a, b)

3) Charcoal of birch beside stone 24 in the E dated at $525 \pm 105$ cal. yrs $\mathrm{AD}(\mathrm{a}, \mathrm{b})$

4) Charcoal from oak and hazel dated at $675 \pm 275$ and $665 \pm 105$ cal. yrs $\mathrm{AD}(\mathrm{a}, \mathrm{b})$

5) A flywheel of red sandstone from the Late Iron Age to Viking time (b)

6) Charcoal of beech at the centre of AS dated at $905 \pm 145$ cal. yrs AD (a, b)

Mound with bones at the shore cliff dated at $985 \pm 45$ cal. yrs AD (a, f)

(a) Mörner, 2015, Table 1 (with additional information), (b) Söderberg et al., 2012, (c) Lund Historical Museum, (d) Ystad Museum, (e) Bob Lind's collection, (f) Mörner, 2011.

There are a lot of finds of tools and objects found in direct association with Ales Stones (Table 1). There are also cup marks and hearth dates. Most of the finds can be assigned to the Late Bronze Age. This is a strong argument in favor of a dating of Ales Stones to the Late Bronze Age. Stratigraphically, the Bronze Age ends with the deposition of a widespread layer of eolian sand dated at 600-400 BC (Mörner, 2015).

The Early Iron Age is represented by a hearth in the cliff section dated at 385 \pm 35 cal. yrs BC. It overlies the first generation of eolian drift and underlies the second generation of eolian drift (Mörner, 2015).

The Middle Iron Age (the Migration period in Sweden, 375-550 AD) is represented by an urn buried in the eolian sand inside the ship, and charcoal found close beside one of the stones (at the outer side of stone N24). The age, $525 \pm 105$ cal. yrs AD, is identical to the age of food left in the urn. Because it was found at the side of one of the big blocks, it implies that Ales Stones must have been erected well before this age (Mörner, 2015); i.e. well before 500 AD.

From the Viking time, there is a charcoal date from the center of the ship. Its implication is not clear, however. From the shore at Kåseberga, there is a mound 
(about $0.5 \mathrm{~m}$ high and $10 \mathrm{~m}$ wide) full of bones (mainly from pigs) and scorched stones. Its surface is covered by stones placed in position by humans (Mörner, 2011, 2015). It provides firm evidence that people have lived in the vicinity during the Viking time.

\subsection{Dates of Objects inside the Ship}

The original surface upon which Ales Stones once was built has a sandy-silty humus soil. It is covered by eolian sand deposited in three main sand drift generations. There was a major gap with soil formation in the period at about 400-1100 AD. The urn and charcoal dated $525 \pm 105$ cal. yrs AD belongs to this soil formation period. Obviously, the finds were buried in the previously deposited eolian sand. The dates indicate that the erection of Ales Stones must be older than $500 \mathrm{AD}$. There are also some dates of charred wood (Table 1), which may signify a growth of trees on the moraine plateau.

\subsection{Date from the Exact Solar Alignment at Winter Solstice}

Today, the Sun is rising not exactly behind or at the edge of the stern stone, but at about $15-17 \mathrm{~cm}$ to the left of the stone (edge to edge) when observing the sunrise at Winter solstice from the center of the ship (Figure 5). From this deviation, Lind calculated that the stones must have been erected at about $700 \mathrm{BC}$ (Lind, 2004, 2005; Lind \& Mörner, 2010). This age fits very well with stratigraphical data and new C14-dates (Mörner, 2015). The deviation observed implies a northward displacement of the Sun's path by $0.77^{\circ}$ in 2700 years.

Astronomer Göran Henriksson has kindly undertaken a high-precision astronomical recalculation of the data (Figure 6). The time when the Sun rose in perfect alignment with the stern stone is $700 \mathrm{BC}$. This lends strong support (not to say final conclusion) to a Late Bronze Age time for the erection of the Ales Stones monument.

Figure 6 is a novel contribution to the discussion of the true age of the Ales Stones monument. It is a very important contribution because it implies that we now have the time quite well locked in the Late Bronze Age. Earlier, there were "greater than" dates but not really any limiting chrono-stratigraphic limit back in time (Mörner, 2015). With the Figure 6 image, the time of the erection of the Ales Stones monument seems to be limited to a fairly narrow time-window at about $700 \mathrm{BC}$, which is 200 years before the end of the Scandinavian Bronze Age.

\subsection{The Occurrence of Cup Marks on Ales Stones}

Cup marks (small round depressions) were predominantly carved into the bedrock in the Bronze Age, but may also occur on carvings from the Neolithic and Early Iron Age. On the outer surface of the stone just to the east of the bow stone, there are cup marks, which form the Swan star constellation (Figure 7) (Lind \& Mörner, 2010). This implies a deep knowledge of and interest in astronomy, typical for the Bronze Age (Mörner \& Lind, 2018; Kristensen, 2010; Bröndsted, 1938; Montelius, 1911). 


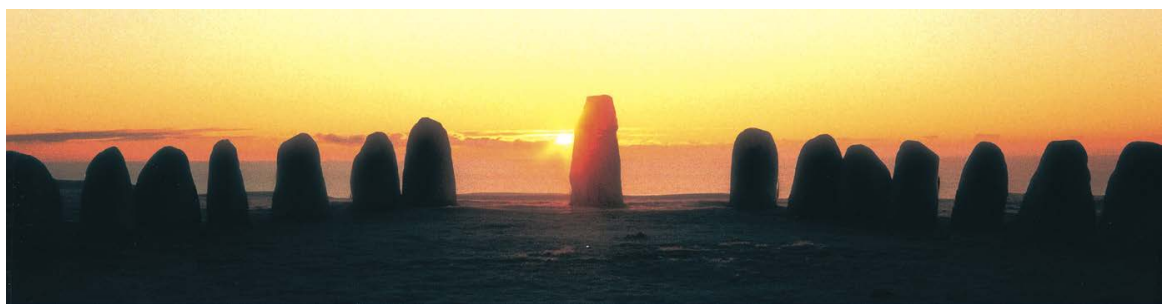

Figure 5. The sunrise at Winter solstice on December 22, 2002 (photo: Bob Lind). The photo was taken from the center of the ship, and the Sun rose $15-17 \mathrm{~cm}$ to the left of the stern stone.

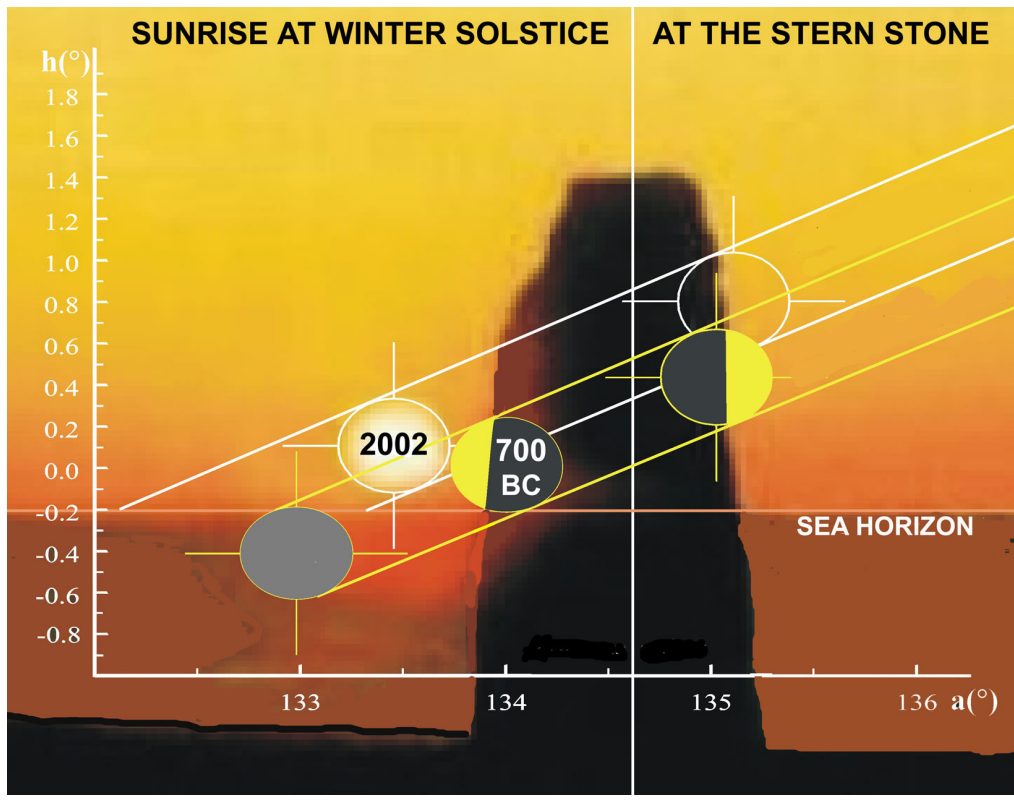

Figure 6. Astronomical high-precision calculation by Henriksson of the deviation between the present sunrise and a sunrise with perfect alignment to the edge of the stern stone (the symmetry axis of the stern stone is given by the white vertical line at $134.6^{\circ}$ ). This alignment occurred $700 \mathrm{BC}$, and it is here proposed to provide a reliable age for the erection of the monument.

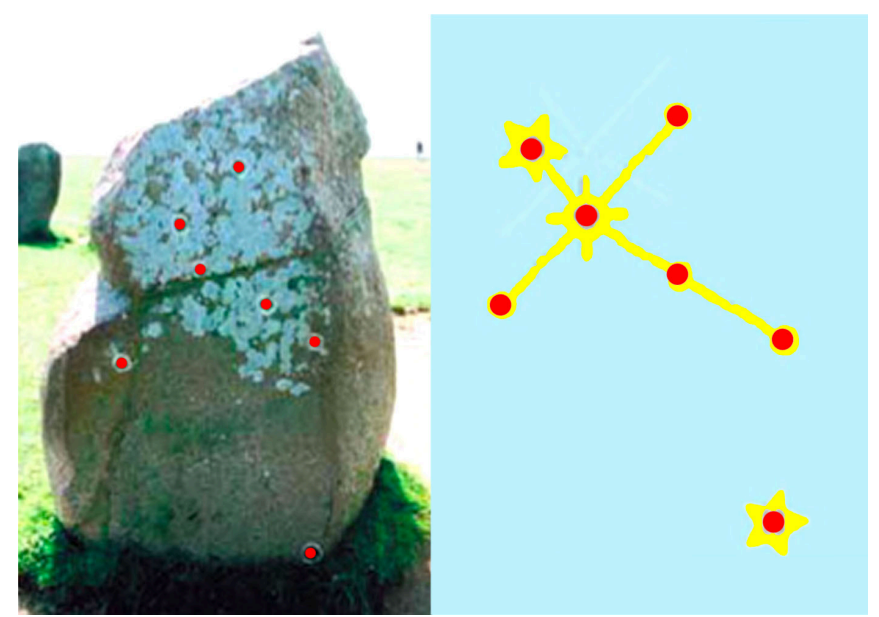

Figure 7. Cup marks on the side of one of the stones in Ales Stones in the form of the Swan constellation (left) and the same constellation as seen in the sky (right). 
Cup marks exist on the top of two stones (the so-called stones $8^{1}$ and $8^{2}$ ); one of 3 cup marks in perfect alignment with the sunrise at Winter solstice (Figure $8(\mathrm{a})$ ), and one of 4 cup marks like a mini ship with perfect alignment to the sunrises at Winter and Summer solstice and the sunset at Summer and Winter solstice (Figure 8(b)).

Cup marks in the form of a star constellation (Figure 7) and cup mark signs in perfect alignment with the sunrise at Winter solstice (Figure 8) are quite clear indications of a Bronze Age construction of the Ale Stones monument.

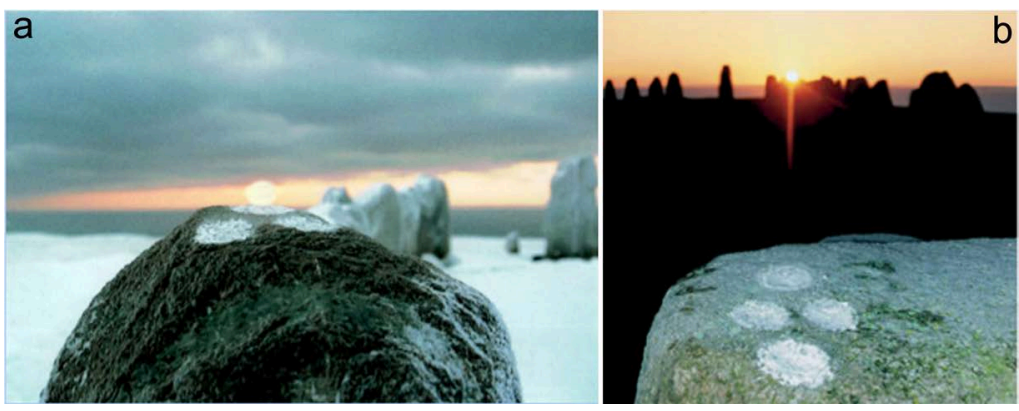

Figure 8. Cup marks on the top of two side stones (number 8 in the SE and number 8 in the NW); one in the form of an aim of 3 marks (a) where the Sun rises right in the aim at Winter solstice, and one in the form of a mini-ship of 4 marks (b) where the Sun rises right along the long-axis of the "ship" at Winter solstice.

\subsection{Stratigraphy and C14-Dates at Ales Stones}

Strömberg, who undertook all the original excavations of Ale Stones, seems to have been focused on finding objects and graves. Therefore, stratigraphic observations are virtually lacking in her reports (Strömberg, 1990, 1992, 1997), like later summaries of her reports (Söderberg et al., 2012). Notions of 60 and $85 \mathrm{~cm}$ of topsoil or humus soil (Swed: "matjord"), of course, represent inadequate sediment identifications.

There are fundamental stratigraphical facts that must be considered, however. This applies both from the moraine hill around the ship and from the shore sections below (Mörner, 2011, 2015). The reference sites are marked in Figure 9.

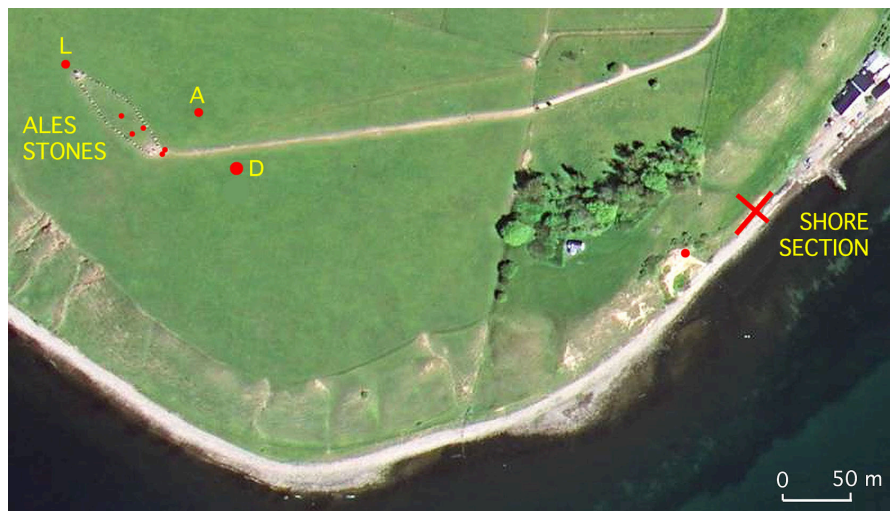

Figure 9. Ales Stones on top of the moraine hill and the shore sections at Kåseberga and other reference sites discussed: red dots at the ship and sites A, L and D (from Mörner, 2015). 


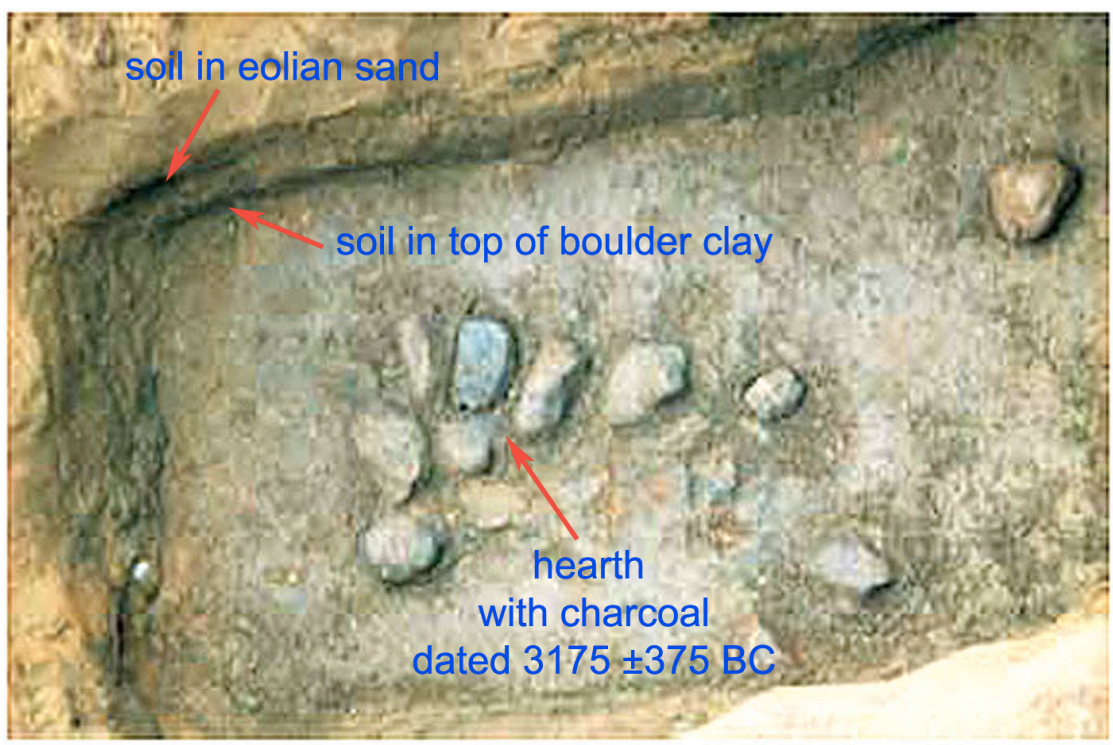

Figure 10. The exposed till surface with a hearth dated at $3175 \pm 375 \mathrm{cal}$ yrs BC (point L in Figure 9) from an excavation in 1995 (photo: Lind, 1995). The till surface is covered by about $90 \mathrm{~cm}$ of eolian sand. It is easy to identify a strong humus soil developed in the top of the till surface (of boulder clay) and a second strong soil separating two units of eolian sand.

\subsubsection{The Moraine Hill}

The hill, upon which Ales Stones are located, is an interlobate moraine of boulder clay and glacifluvial material. The age of the moraine is about 14,000 BP. On top of the moraine, there is a soil from an exposed land period lasting from about 12,000 to $600 \mathrm{BC}$. The Ales Stones monument is built on this surface. All the tools and objects from the Bronze Age (Table 1, nos. 4 - 13) and the two charcoal dates from the Neolithic (Table 1, nos. 1 - 2; Figure 9, points L and A) are found on this surface.

This ancient soil surface is covered by eolian sand deposited in a succession of phases and interrupted by non-depositional intervals. At one of the non-depositional intervals, there was quite a strong soil formation (Figure 10). This soil is very well expressed in the shore section (below; Mörner, 2015). It seems to have lasted from the Roman Iron Age up to the end of the Viking time or from about 200 up to $1100 \mathrm{AD}$. This implies quite a long time with an exposed land surface with soil formation and growth of trees and shrubs. The urn was buried in the sand below this surface (Figure 11). The urn is standing on the soil surface of the boulder till. It includes food remains dated at $525 \pm 105 \mathrm{cal}$. yrs AD and charcoal dated $400 \pm 150$ cal. yrs $\mathrm{AD}$ (providing minimum ages of the onset of the second soil horizon). Finds of birch ( $525 \pm 105 \mathrm{AD})$, oak $675 \pm 275 \mathrm{AD})$, hazel $(665 \pm 105 \mathrm{AD})$ and beech $(905 \pm 145 \mathrm{AD})$ have been dated to this period (Table 1, Iron Age, nos. 2 - 5), which implies that the soil formation period was also a period with trees and shrubs covering the hill. Furthermore, there are several finds of depressions in this surface, which represent the removal of stones and blocks for the construction of the monument (Mörner, 2011). 

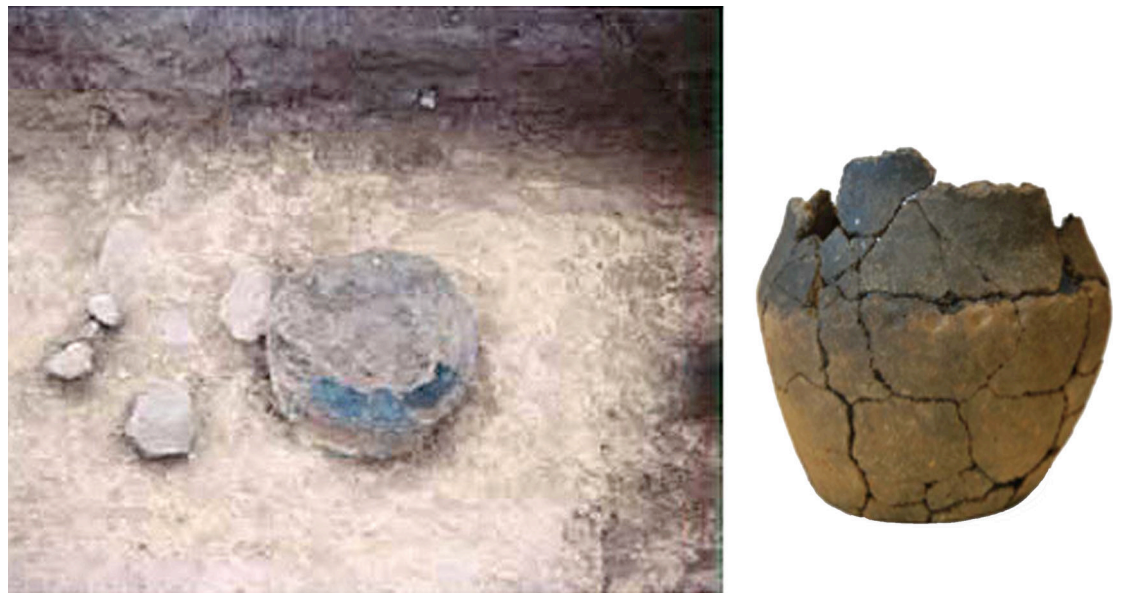

Figure 11. The urn from inside the ship. It is buried in the eoliand sand below the second soil horizon, and placed in standing position on the old till surface. The two dates (400 \pm 150 and $525 \pm 105 \mathrm{cal} \mathrm{yrs} \mathrm{AD)} \mathrm{provide} \mathrm{a} \mathrm{minimum} \mathrm{age} \mathrm{of} \mathrm{the} \mathrm{second} \mathrm{soil} \mathrm{horizon.}$

The depth of the eolian sand deposits covering the old till surface is on the order of $60-90 \mathrm{~cm}$ in the ship itself. It includes one very distinct soil horizon (Figure 10). The covering eolian sand is from the periods of intensive sanddrift in medieval time and from the period of deforestation and plowing starting in the $19^{\text {th }}$ century. The plowing lead to intensive sand drift and the monument acted as a trap where large quantities of sand accumulated, calling for major sand clearing in1956 (Lind, 2018).

In 2011, we undertook excavations on the plane to the east of Ales Stones (Figure 9, site D), where several of the objects from the Late Bronze Age had been found (Table 1, Bronze Age, nos. 4, 6, 7 and 12). In the five excavation pits (A-E), we only found pieces of flint, all of which had a touch-up typical for the Late Bronze Age (E. Jonsson in Mörner, 2011).
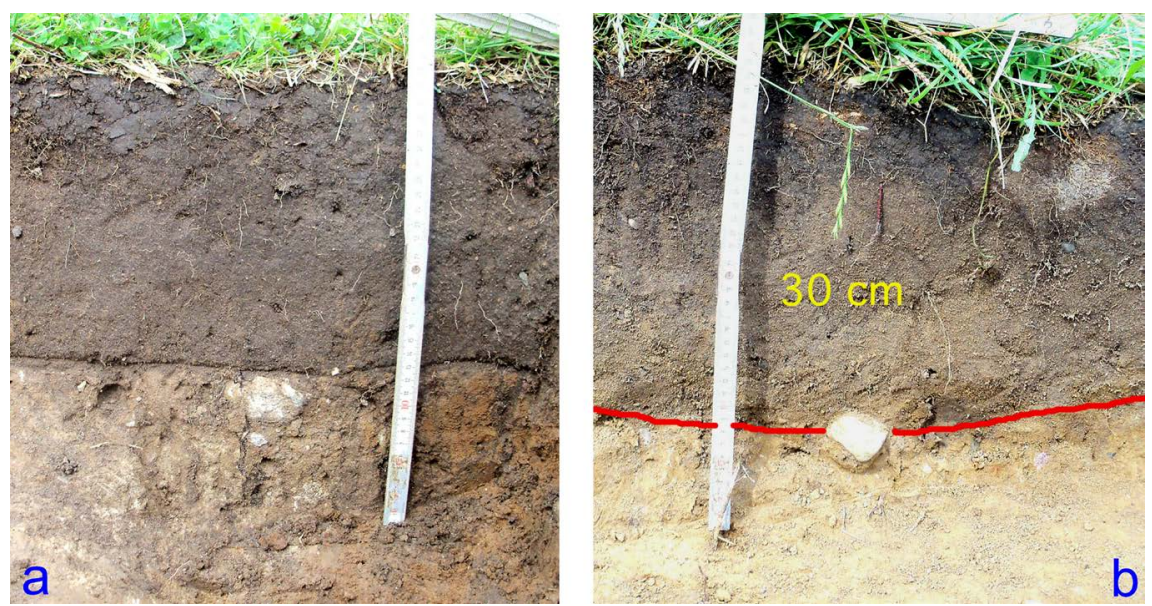

Figure 12. Stratigraphy exposed at our 2011 excavation at Ales Stones (Mörner, 2011). (a) The usual stratigraphy: $25 \mathrm{~cm}$ of plow-stirred humus soil directly covering the old till surface (a stony boulder clay, often weathered into a brownish-yellowish colour); (b) 30 $\mathrm{cm}$ sediment cover with a $12 \mathrm{~cm}$ topsoil in eolian sand. 


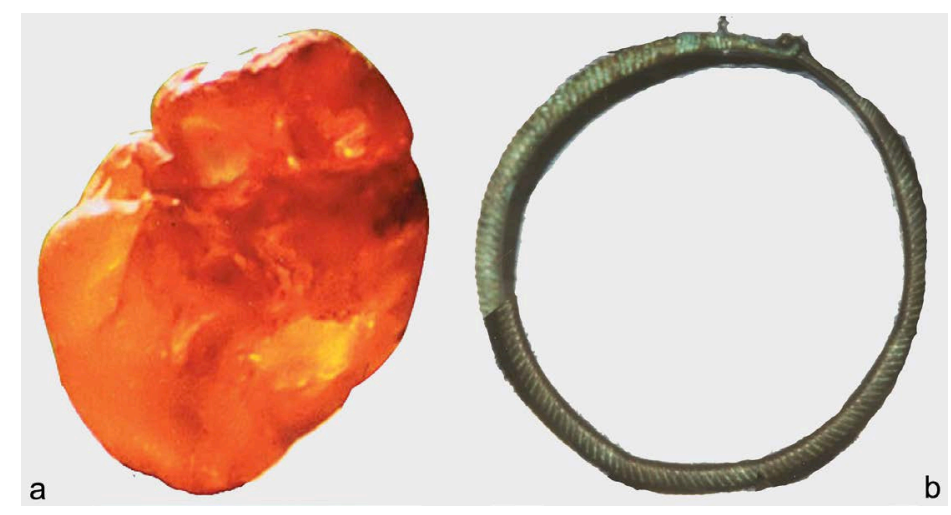

Figure 13. Two of several artifacts found when plowing down to the till surface (Table 1). (a) An owl of amber found in 1953 (now co-owned by Mörner \& Lind); and (b) A neck-ring of bronze found in 1937 (now at Ystad Museum).

On the plane east of Ales Stones, the old till surface is covered by only about $20-40 \mathrm{~cm}$ of eolian sand (except for depressions where the cover may go up to $40-60 \mathrm{~cm}$ ). In most places the stirring by plowing has reached all the way down to the till surface exposing a black humus soil from the ground surface down to the till surface (Figure 12(a)). In a few places the ground has remained undisturbed and there is a normal humus soil of about $12 \mathrm{~cm}$ in the top of the eolian sand (Figure 12(b)).

Most of the artifacts found on the plane surrounding Ales Stones were found by the farmers when plowing the fields (Figure 13). Predominantly, they all belong to the Late Bronze Age (Table 1).

At our excavation in 2011, Mörner (2011) observed that there was an imprint in the bounder clay from a big block of about $3 \mathrm{~m}$ in length and $1 \mathrm{~m}$ in width (Figure 14). Obviously it had been broken-up out of the till surface by the builders of Ales Stones. There were even marks in the ground from the process of breaking it out of the till.

The depression is filled with eolian sand from the period of extensive sand drift 600-400 BC (Mörner et al., 2009; Mörner, 2011, 2015). As there were no sediments in the depression, it is likely that the removal of the block occurred shortly before the sand drift starting in $600 \mathrm{BC}$.

In Figure 15 we compare the size of the imprint with stone S26 (the second on the south side from the stern stone). The agreement is reasonably good. Even other blocks could be considered, however. The height of the stone is $1.5 \mathrm{~m}$, and this level is marked with a green bar in Figure 15. When the stones were put in place the ground level was about $60-70 \mathrm{~cm}$ lower as marked with the blue line, implying that about $1 \mathrm{~m}$ of the block was rooted in the till (and fixed in place by foot stones pounded into the boulder clay).

It is of great importance that the big boulder was bent out of position in the surface of the till by humans for the obvious purpose of using it for the building of Ales Stones. Because the imprint in excavation pits D and B (Figure 14 \& Figure 15) was filled by eolian sand dated 600-500 BC, the building of Ales Stones must be older than $600 \mathrm{BC}$. 


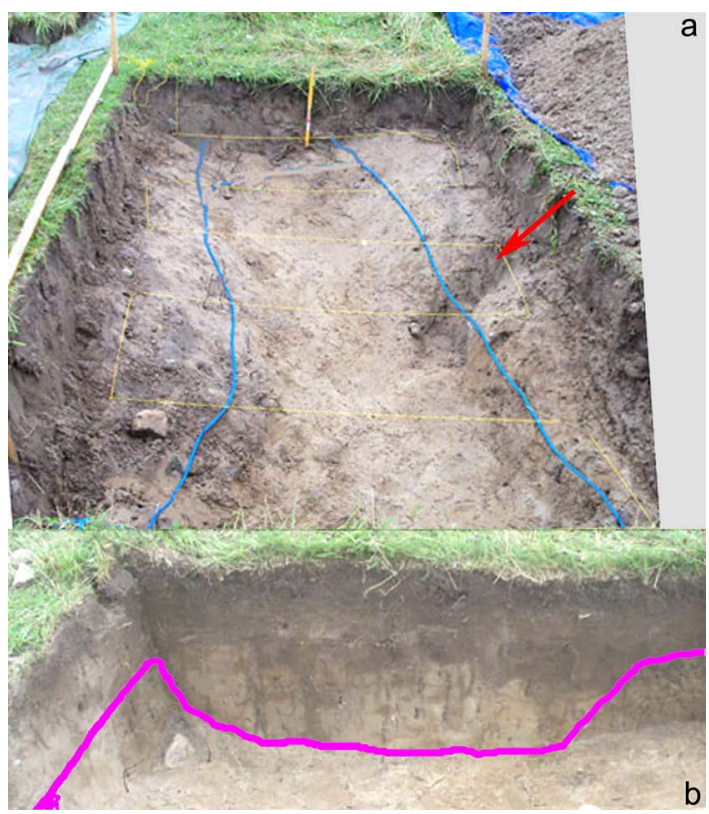

Figure 14. Imprint of a huge block $(3 \times 1 \mathrm{~m})$ in the boulder clay surface (purple line marking a $0.5 \mathrm{~m}$ deep and $1 \mathrm{~m}$ wide depression in the till). Arrow shows the mark of a rod pushed down to bend the block out of the ground. The imprint was filled by eolian sand from the sand drift period 600-400 BC. Consequently, the removal of the block must have occurred before 600 BC. (a) Refers to excavation pit D with the blue rope marking the edges of the imprint; (b) The perpendicular section of the imprint (observed in excavation pit B) with a sediment depth of $95 \mathrm{~cm}$ consisting of two sedimentary cycles: the upper $35 \mathrm{~cm}$ with the present top soil and the lower $60 \mathrm{~cm}$ of post-600 BC eoliand sand with a weak top soil.

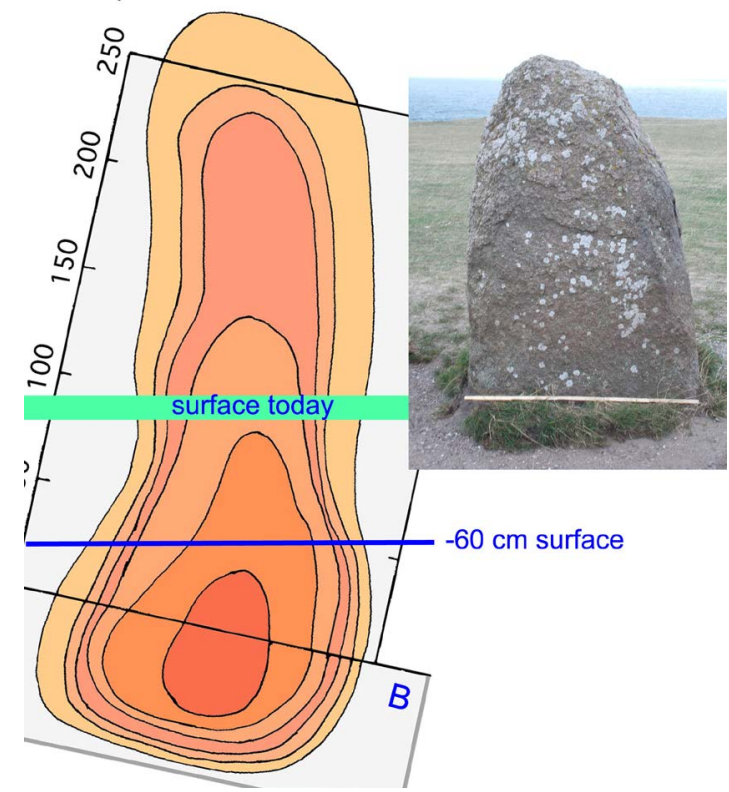

Figure 15. The imprint documented in excavation pits B and D (Mörner, 2011, 2015) compared to Block S26 (the second block on the southern side from the stern stone). The green bar across the imprint marks the present ground surface. The blue line gives the approximate position of the ground surface when the ship was built, implying that about $2 \mathrm{~m}$ of the block was sticking up, and about $1 \mathrm{~m}$ was rooted in the boulder clay. 


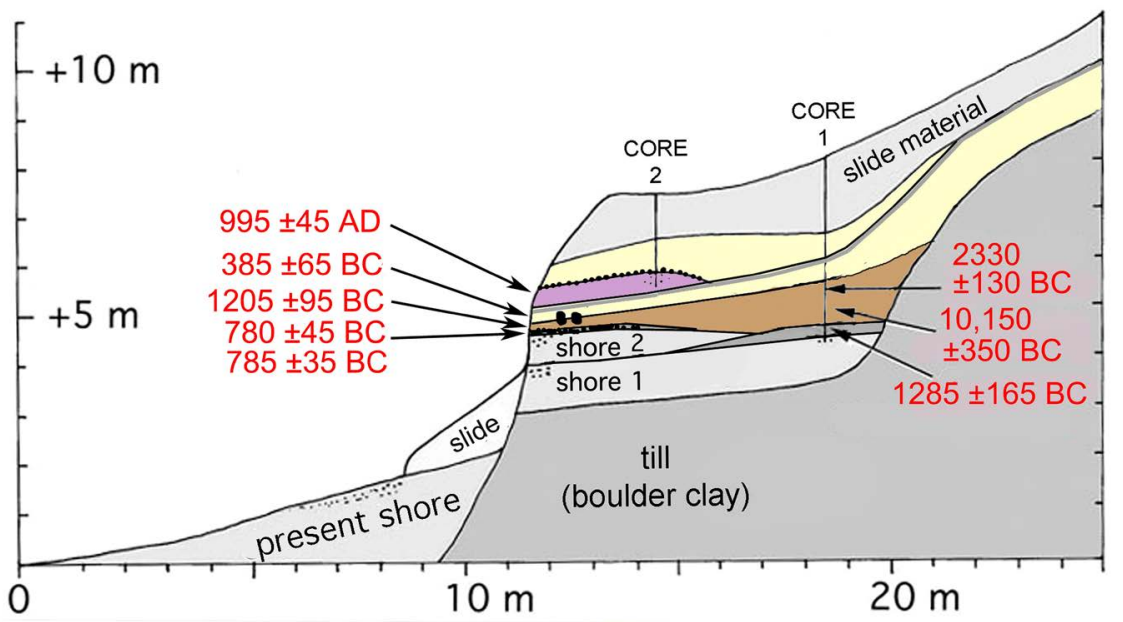

Figure 16. Stratigraphy and C14-dates from the shore section at Kåseberga, downhill of Ales Stones (form Mörner, 2011, 2015). Black layer = fire surface, brown layer = earthquake layer, and purple layer $=$ mound with bones and burned stones from the Viking time.

\subsubsection{The Shore Cliff}

In the shore cliff to the west of Kåseberga and just downhill from Ales Stones (Figure 9), there is an excellent stratigraphic record covered by profiles along the cliff and perpendicular to the cliff (Mörner, 2011, 2015). A total of 8 C14-dates were obtained in this section, which led to the establishment of a very clear stratigraphy (Figure 16).

At the base, there is a boulder clay from the deglaciation period, with an erosional unconformity covered by shore 1 from around $2600 \mathrm{BC}$.

Shore-2 has a known age of 1000-750 BC. It is underlain by a humus soil C14-dated at $1285 \pm 165$ cal. yrs BC, and overlain by a black layer of humus and burned remains (a fire surface) C14-dated at $785 \pm 35$ and $780 \pm 45$ cal. yrs $\mathrm{BC}$.

It is covered by an earthquake layer (Mörner, 2014, 2015) with re-deposited material as indicated by older C14-dates: $1205 \pm 95$ (bone), $2330 \pm 130$ (gastropod) and 10,150 \pm 350 (marine shells) cal. yrs BC.

Directly above this layer lies eolian sand. This represents a well-known period of general sand-drift at the Sub-Boreal/Sub-Atlantic boundary at about 500 BC. In Mörner et al. (2009) this first general sand drift (Sand-Drift-1) is bracketed by two C14-dates: $467 \pm 45$ and $604 \pm 126$ cal. yrs. BC (providing a firm age of this sand drift period of $600-450 \mathrm{BC}$ ). It is covered by a weak soil with a heath dated at $385 \pm 65$ cal. yrs BC.

A second eolian unit follows, which ends in an extensive soil horizon, representing most of the Late Iron Age and the Viking time. On this soil horizon there is a mound (or midden) of about $0.5 \mathrm{~m}$ in height and $5 \mathrm{~m}$ in diameter. It is full of bones (mainly of young pigs) and stones affected by burning. The surface consists of stones placed in position by people (Mörner, 2011, 2015). A bone was C14-dated at $995 \pm 45$ cal. yrs AD, implying the Viking time. 


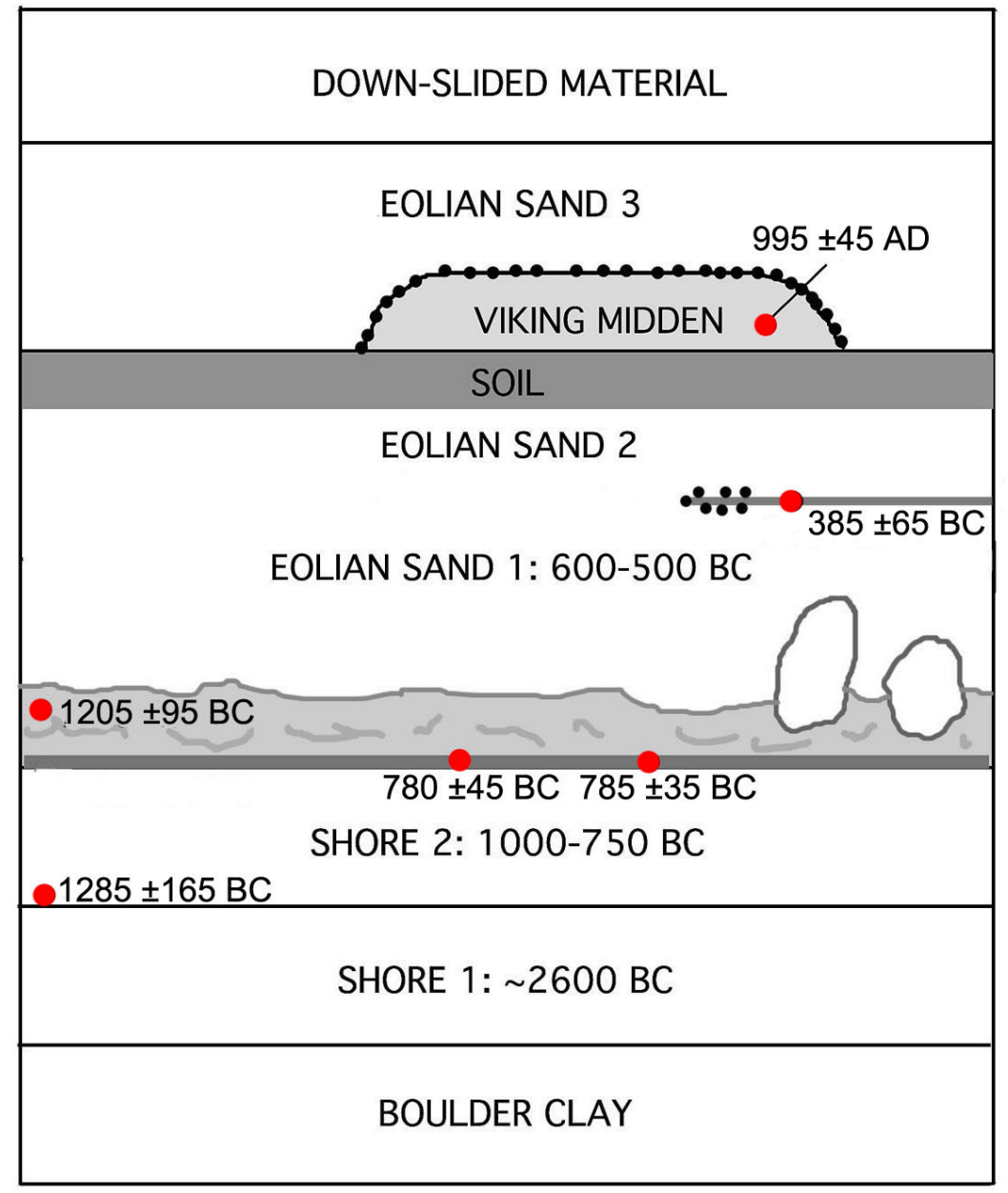

Figure 17. Composed stratigraphy and C14-dates from the shore section at Kåseberga.

The soil horizon and Viking mound (midden) are covered by a third layer of eolian drift. Obviously, it dates from medieval time. At Vitemölle, Mörner et al. (2009) dated the onset of this period of general sand drift (Sand-Drift-2) at 1345 \pm 38 and $1415 \pm 12$ cal. yrs AD. Finally, there is a layer of down-slide material, which belongs to the last century's human and animal activity.

Figure 17 summarizes the stratigraphy in the shore section. It has a fundamental bearing on the interpretation of the stratigraphy and chronology of the building of Ales Stones. The main eolian drift covering the original ground floor in Ales Stones (Figure 10) and the imprint of the block (Figure 14) have to be identical to the "eolian sand 1" unit in Figure 17 with an onset of deposition at $600 \mathrm{BC}$. The strong soil horizon in the shore section must be an equivalent to the buried soil at Ales Stones (Figure 10). It represents a hiatus of considerable time: at least 600 years from 400 to $1000 \mathrm{AD}$, but probably about double that time, from about 0 to $1350 \mathrm{AD}$.

During this interval, the urn (Figure 11) was buried inside the ship and the charcoal and bone fragments just outside stone N24. Trees and shrubs (birch, oak, hazel, etc.) grew on the exposed land surface. During the Viking time, it 
seems that the centre of the stoneship was used as a firebox. The beech wood dated at $905 \pm 145 \mathrm{cal}$. yrs $\mathrm{AD}$ is an excellent firewood. In combination with the midden (or mound) dated at $995 \pm 45$ cal. yrs. AD (Mörner, 2011, 2015; Figure 17) it indicates that the area hosted intense activity by people during the Viking time. This was an activity linked to a re-use of the existing old ship monument, and has nothing to do with the time of construction.

\section{The 4 Quartzite Blocks: Quarrying and Shipping}

Ales Stones has 4 blocks consisting of quartzite: the two huge megaliths erected as bow stone and stern stone, and the two extended ram stones termed the altar stone and the rudder stone. These four blocks have sharp angular edges and fracture marks indicating that they have not been transported to the region by the land ice (as all the other blocks in Ales Stones have), but must have been quarried from an in situ quartzite bedrock. This was already proposed by Bergström et al. (1988), and they pointed out the coastal area between Gislövshammar and Simrishamn.

We claim that we have found the exact place from where the four blocks originate; viz. Branteträsk in Brantevik (between Gislövshammar and Simrishamn), some $20 \mathrm{~km}$ to the northeast of Ales Stones (Mörner, 2012b, 2014, 2015, 2017a).

In 2009, we found fractured quartzite blocks in a forested area at Brantevik. After extensive cleaning, it became obvious that a large area of quartzite bedrock had been fractured up in large angular pieces by an earthquake (Figure 18).

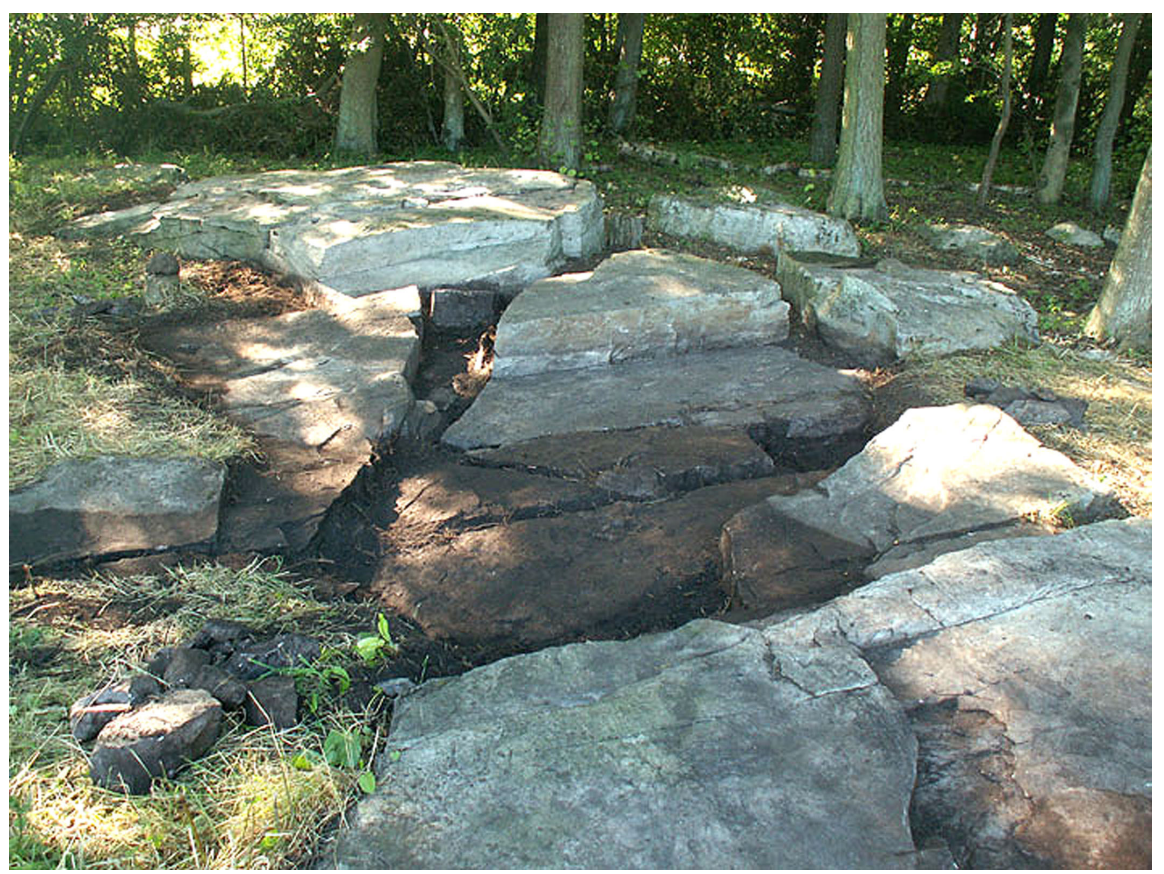

Figure 18. A quartzite bedrock fractured into angular blocks with knife-sharp edges. The surface is weathered and glacially scoured. The origin is a seismic deformation 750 BC (Mörner, 2014). 
The bedrock surface at Branteträsk (the name of the site of quartzite bedrock deformation and quarrying) is heavily fractured into blocks (Figure 18). The original fracturing can only have originated from a major earthquake generating extensional forces in two perpendicular directions (Mörner, 2012b, 2014; Mörner \& Lind, 2013). Traces of this earthquake have been recorded over an area of about $70 \times 20 \mathrm{~km}$ and include post-carving fracturing of petroglyphs from the Bronze Age (Mörner, 2012a, 2012b, 2014). The magnitude was estimated at about 6.3 - 6.8 (Mörner, 2014). This earthquake was dated at about 780 BC (Mörner, 2014).

After the earthquake fracturing, people must have turned the site (well prepared with its bedrock surface fractured up into loose individual blocks) into an "industrial" quarry. This quarrying is evident from the removal of flat quartzite discs from the bedrock blocks, and from a block piled up in inclined position ready to be transported away (Figure 19).

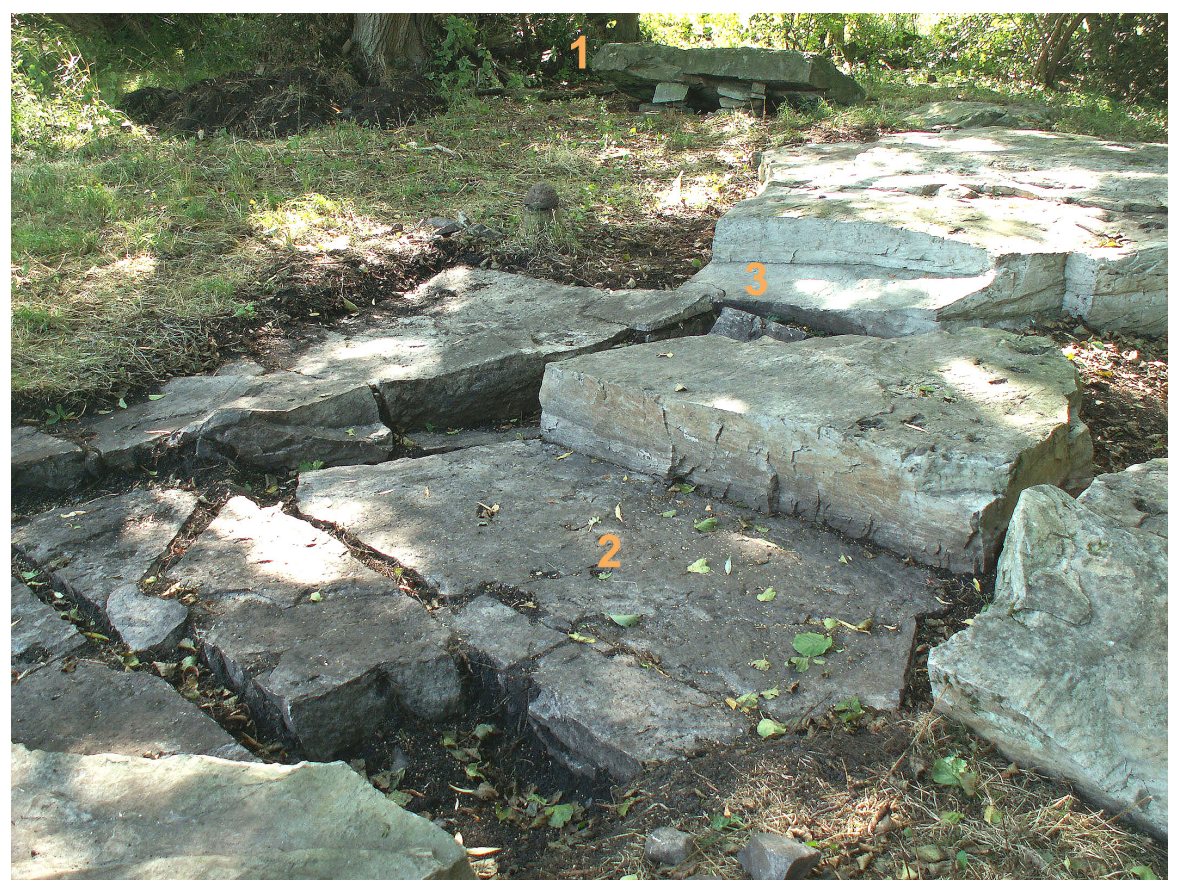

Figure 19. The pieces of deformed quartzite bedrock have undergone a second deformation by people breaking-off large discs (i.e. using the blocks for quarrying). In the background, there is a piled-up bedrock (1) and in the quartzite surface one can identify the removal of large discs $(2,3)$.

The grain size and internal bedding of the quartzite at Branteträsk are identical to that of the bow and stern stones in Ales Stones (Figure 20, arrow 2). The surface structures of the old bedrock surface at Branteträsk is strongly weathered and traversed by glacial scouring structures identical to the old surface of the bow stone in Ales Stones (Figure 19, arrow 1). Therefore, we are quite sure that the quartzite blocks in Ales Stones were quarried at Branteträsk and transported to Ales Stones by rafts or boats (Figure 21). 


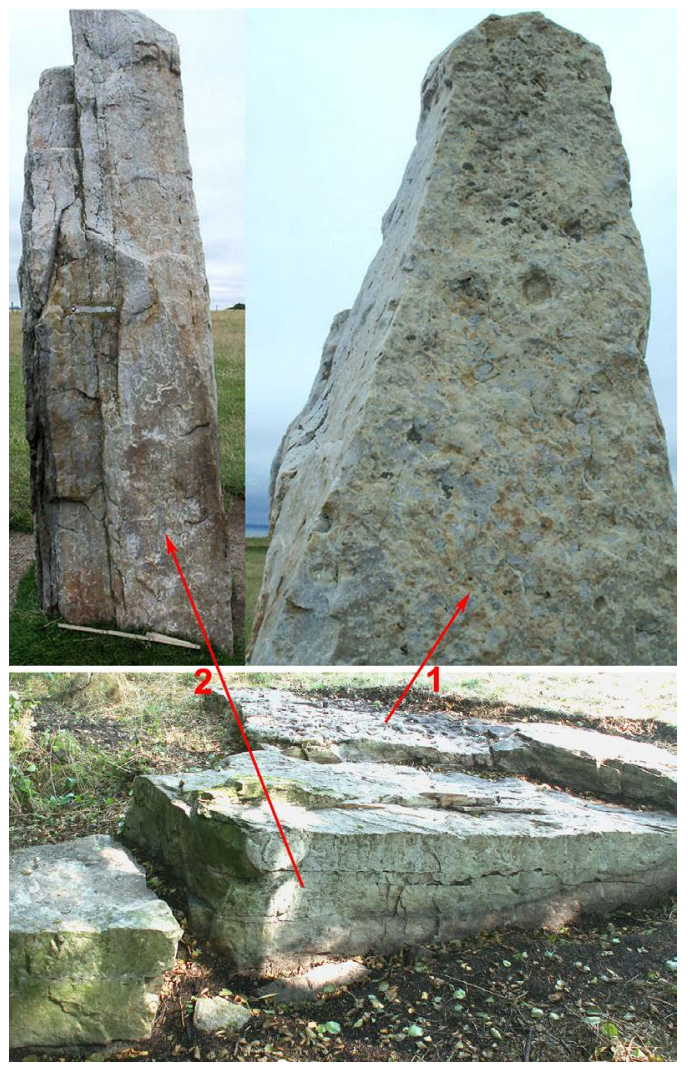

Figure 20. Comparison between the surface weathering pattern (1) and the internal bedding pattern (2) of the stern and bow stones in Ales Stones (above) and the blocks at Branteträsk (below). The similarities are very close, not to say identical, lending strong support to our proposition that this was the place of the quarrying of the quartzite blocks now being the bow stone and the stern stone plus the two ram stones (i.e. the rudder stone and the altar stone) in Ales Stones.

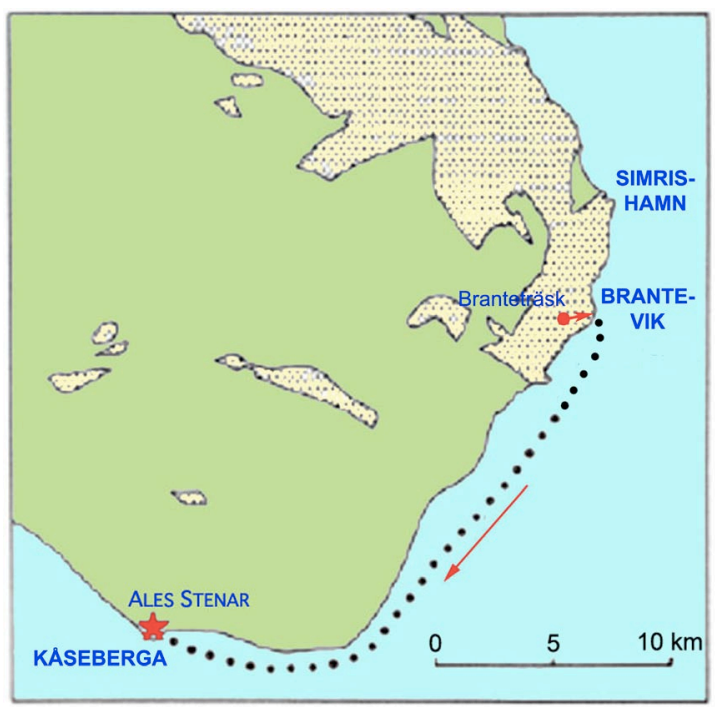

Figure 21. The transport route of the 4 quartzite blocks from their quarrying at Branteträsk via rafts or boats from Brantevik to Kåseberga up to their erection in the stone ship of Ales Stones (a distance of $30 \mathrm{~km}$ ). Dotted areas represent the occurrence of Cambrian quartzite bedrock in situ. 
The fracturing of the quartzite bedrock surface (Figure 18) is dominated by extension forces in the E-W, NNE-SSW and NW-SE directions (Mörner, 2014). This fracture opening can never have been achieved by human activity and can only be understood in terms of a significant seismic event. Paleoseismic criteria (bedrock fracturing at 13 sites, fracturing of rock-carvings from the Bronze Age at 7 sites and liquefaction at two sites $43 \mathrm{~km}$ apart) indicate a seismic magnitude of about M 6.3 - 6.8 (and intensity VIII-IX) with the epicenter at Glimmingehallar $3 \mathrm{~km}$ to the west. The dating of the event (by radiocarbon, archaeology and sea level history) seemed well established at 780-750 BC.

Subsequent studies and C14-dating have revealed that there were, in fact, two earthquakes: one at around $3000 \mathrm{BC}$ and one (as previously described) at 780-750 $\mathrm{BC}$. It does not change the timing of the quarrying at Branteträsk and transport of the blocks to Ales Stones, however.

At Brantevik, there was a grave, known as Brantarör, from the Late Bronze Age (Lind, 2011). It included some bronze objects, a rock-carving of a sun-symbol (typical for the Bronze Age) and an urn dated at 800-300 BC (Figure 22). It also included some 75 huge blocks of quartzite, indicating intensive quarrying at around 700 BC (Mörner, 2015).

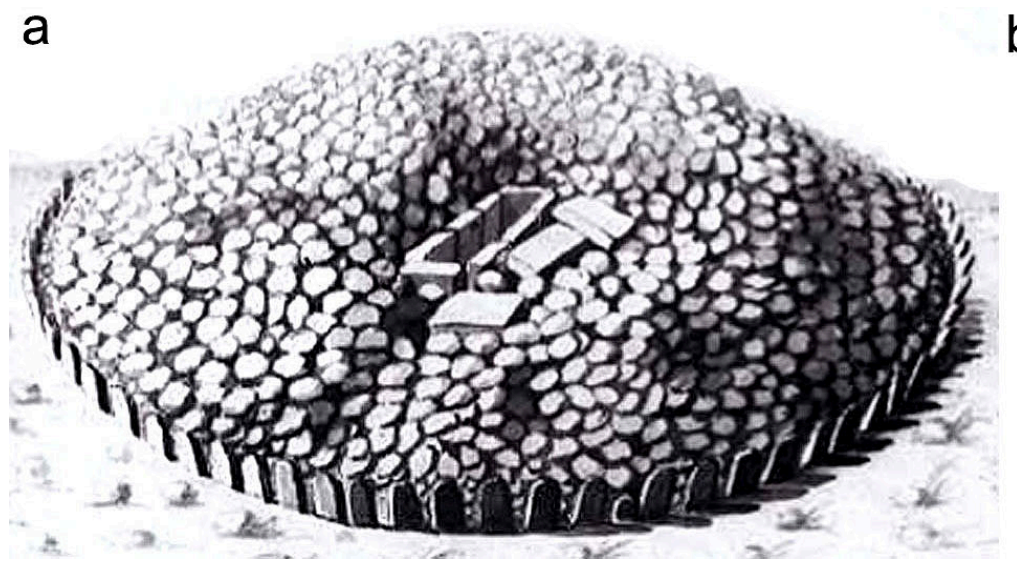

b

Figure 22. (a) The Brantarör grave as drawn by Hilfeling (1777). The sarcophagus included a hilt of bronze and an urn (b), and a sun symbol was cut in one of the stones. This indicates that the grave belongs to the Bronze Age. The urn is quite unique and was dated at 800-500 BC; i.e. the Late Bronze Age (Lind, 2011; Mörner, 2015).

The Brantarör grave (Figure 22(a)) is surrounded by about 60 curbstones and the sarcophagus consists of 14 big blocks. All of these blocks are flat quartzite blocks that must have been quarried in the close vicinity. The obvious place of a quarry of nearly industrial dimensions is Branteträsk, $600 \mathrm{~m}$ to the SW (Figure 23), and we see a logical chain of events: 1) a seismic fracturing of the quartzite bedrock, 2) a human utilization of the site for quarrying flat quartzite blocks, 3) a transport of blocks to be used in the building of the Brantarör grave (about 74 blocks) and 4) a shipping of four blocks to be erected in Ales Stones (the bow and stern monoliths, plus the altar stone and the rudder stone) as illustrated in Figure 23 (Mörner, 2015, 2017a). 


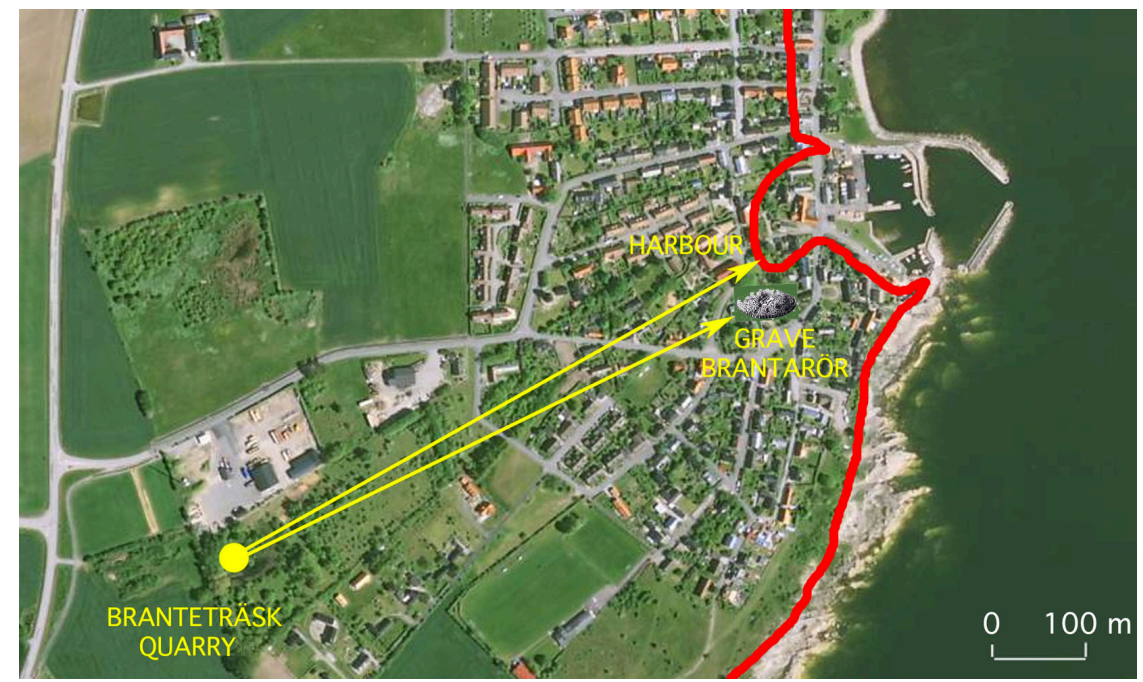

Figure 23. The quartzite blocks quarried at Branteträsk were transported $600 \mathrm{~m}$ to the NE partly for the building of the Brantarör grave (74 blocks) and partly for transport to Ales Stones ( 4 blocks) via the natural harbour when sea level was at $+2.1 \mathrm{~m}$ in the period 1000-750 BC and sea transport as shown in Figure 21 (from Mörner, 2015).

Obviously, the Brantarör grave dates from the Late Bronze Age (Lind, 2011; Mörner, 2015; Mörner, 2017a). There are a number of graves at Brantevik (Lind, 2011). It seems significant that they exhibit an alignment with respect to the Sun (Lind, 2011). The "southern grave" lies $1.2 \mathrm{~km}$ to the SW of the Brantarör grave. At Summer solstice, the Sun rises right over the Brantarör grave when viewed from the southern grave (Lind, 2011). This is another factor linking the Brantevik area to the Ales Stones monument and its erection in the Late Bronze Age (Mörner, 2015).

\section{The Function of the Ales Stones and Related Monuments}

We have reviewed the dating of Ales Stones, indicating a time of erection of the monument of about 750-700 BC, and it is now time to review the function of the monument. Lind $(2004,2005)$ showed that the monument must have worked as a sophisticated astronomical calendar in good agreement with earlier proposals (Alfredson \& Meurling, 1976; Lind, 1977; Carter \& Malmström, 1979; Roslund, 1979) and later verifications (Lind \& Mörner, 2010; Mörner \& Lind, 2012, 2013; Mörner, 2015).

\subsection{Ales Stones as a Calendar}

The $69 \mathrm{~m}$ long stone ship was erected on the top of the Kåseberga hill with a remarkable view over the sea (Figure 1). The position of the individual stones (57 plus 1 missing) is arranged in a very close (not to say exact) relation to the Sun's annual and daily motions over the sky (Lind \& Mörner, 2010, p. 96 and 98, respectively).

The construction of the stone ship is shown in Figure 24. Every stone has a number beginning with number 1 in the bow stone in the NW and 1 in the stern stone in the SE. The following main solar alignments are recorded of the Sun's annual motions: 


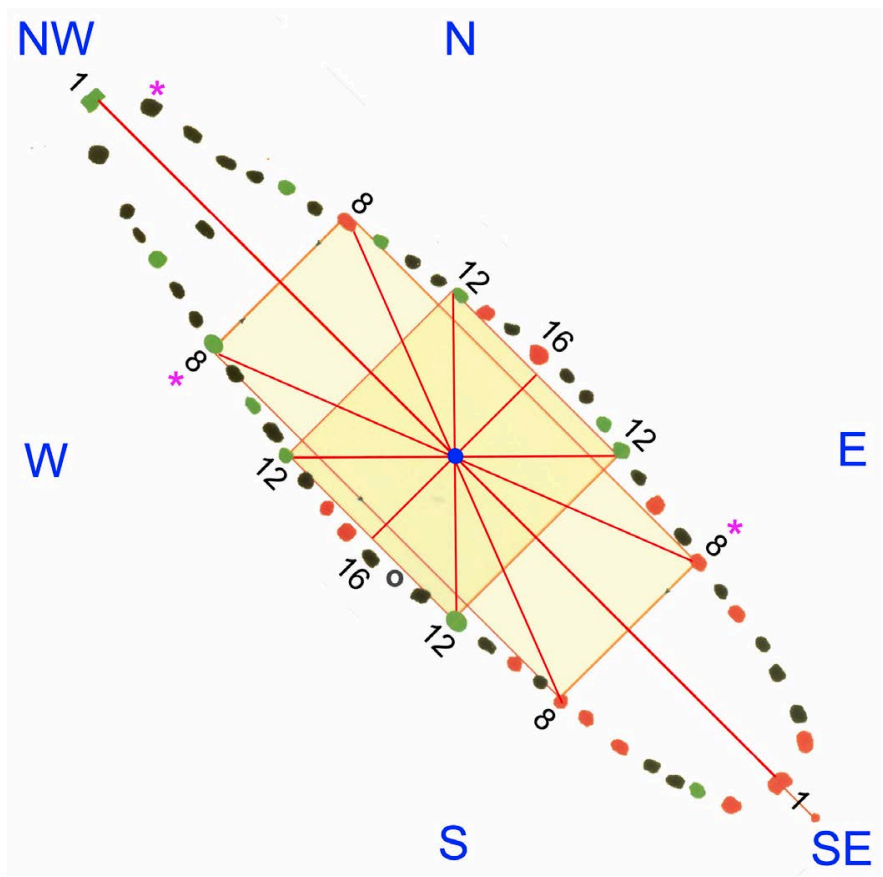

Figure 24. The geometry, position of stones and geographic orientation of Ales Stones. The long-axis is in NW-SE with sunrise at Winter solstice at the stern stone in the SE and the sunset at Summer solstice at the bow stone in the NW. Stone colouring: red $=$ in place, green $=$ tilted, black $=$ fallen before restauration in 1916 (Lind, 2018). Asterix signs denote cup marks. Basic geometric concepts: the NW-SE long-axis, the stone 8 rectangle, the stone 12 square and the central point (blue dot). The arrangement of stones gives a sophisticated astronomical annual calendar and sundial (Lind, 2005; Lind \& Mörner, 2010) as further discussed below.

- Sunrise at Winter solstice over stone 1 in the SE (Figure 4).

- Sunset at Winter solstice over stone 16 in the SW.

- Sunrise at Spring Equinox over stone 12 in the E.

- Sunset at Spring Equinox over stone 12 in the W.

- Sunrise at Summer solstice over stone 16 in the NE.

- Sunset at Summer solstice over stone 1 in the NW (Figures 4-6).

- Sunrise at Spring Equinox over stone 12 in the E.

- Sunset at Spring Equinox over stone 12 in the W.

On the top of stones 8 in the SE and stone 8 in the NW, there are cup marks (Figure 25) as shown and discussed in Lind \& Mörner (2010), Mörner (2015, Figure 18) and Lind (2017, Figure 3 and Figure 5). The cup marks in a triangle on top of stone 8 in the SE give a perfect alignment to the sunrise at Winter solstice (Figure $8(\mathrm{a})$ ). The cup marks as a ship on top of stone 8 in the NW record the 4 solar turning-points during a year (Figure 8(b)).

The fact that the cup mark signs and the main ship itself (Figure 25) give exactly the same alignments with respect to the Sun's main annual positions indicates beyond doubt that we are dealing with sophisticated astronomical calendar alignments (it is, of course, impossible that these perfect solar alignments would have been achieved by coincidence). 


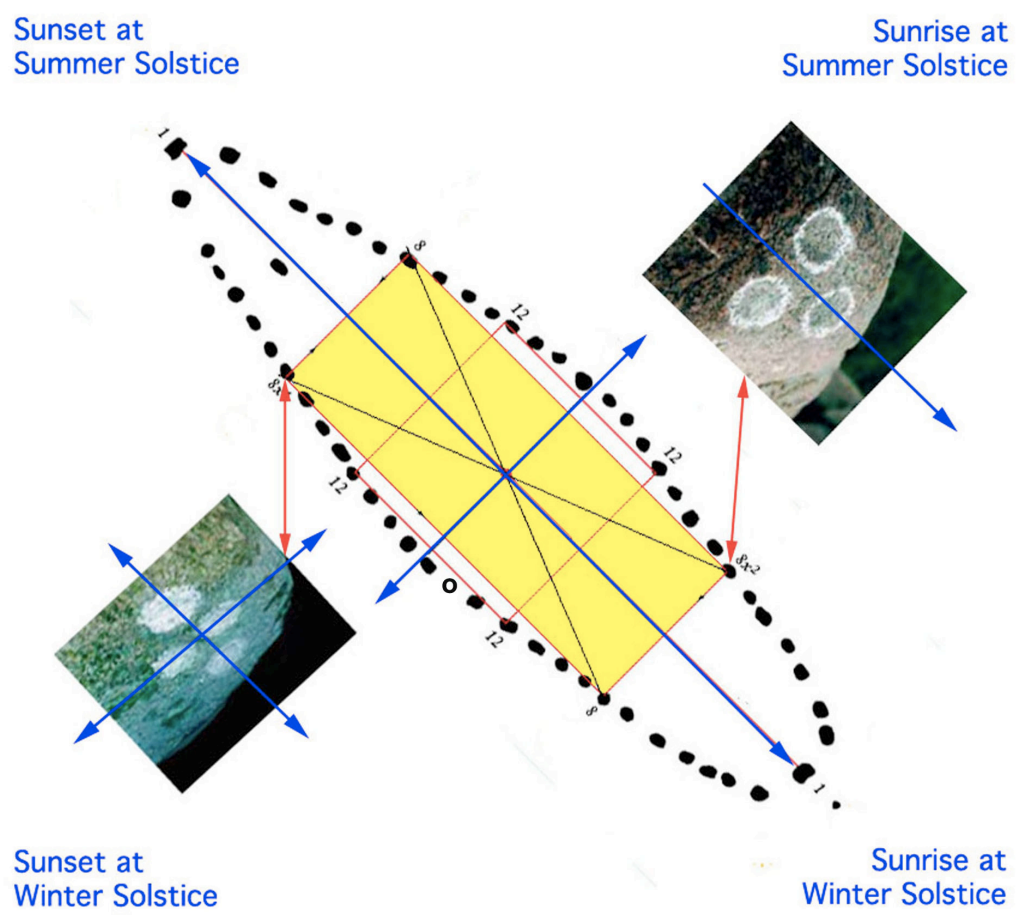

Figure 25. The 4 main solstice positions (blue arrows) of alignments of the ship itself and the two cup mark figures (from Mörner, 2015).

There is also a monthly organization of Ales Stones (Figure 26; cf. Lind, 2005; Lind \& Mörner, 2010: p. 97). After the sunrise at Winter solstice over stone 1 in the SE, the point of sunrise moves in steps of 30 days (i.e. 1 month) to the southwest to stone 3 (January 23), stone 9 (February 22), stone 12 (March 24), stone 14 (April 23), stone 15 (May 23) and then stone 16 (June 22 at the Summer solstice). The next half calendar year continues with the position of the sunset at Summer solstice over stone 1 in the NW moving to the southeast to stone 3 (July 27, making this month 35 days long), stone 9 (August 26), stone 12 (September 25), stone 14 (October 25), stone 15 (November 24) and then stone 16 (December 24 at the Winter solstice). This completes one circuit around Ales Stones and one calendar year consisting of 11 months of 30 days and 1 month of 35 days (the June-July 35 days month) giving a full year of 365 days. This is why there is a larger gap between stones 2 and 3 in the NW. All the 14 sunrise and sunset positions have been documented by Lind (Lind \& Mörner, 2010: p. 94).

Ales Stones also works as a huge sundial (Figure 27; cf. Lind, 2005; Lind \& Mörner, 2010). The stone ship can be divided up in 16 segments each representing 1.5 hours making a full day of 24 hours. Placing a long rod in the centrum point (with a dip to the north of about $25^{\circ}$ ), its shadow will move as follows:

- On stone 16 in the SW at 03.00 o'clock (sunrise at Summer solstice).

- On stone 14 in the WSW at 04.30 o'clock.

- On stone 12 in the $\mathrm{W}$ at 06.00 o'clock at (sunrise at the Equinoxes).

- On stone 8 in the WNW at 07.30 o'clock.

- On stone 1 in the NW at 09.00 o'clock at (sunrise at the Winter solstice). 


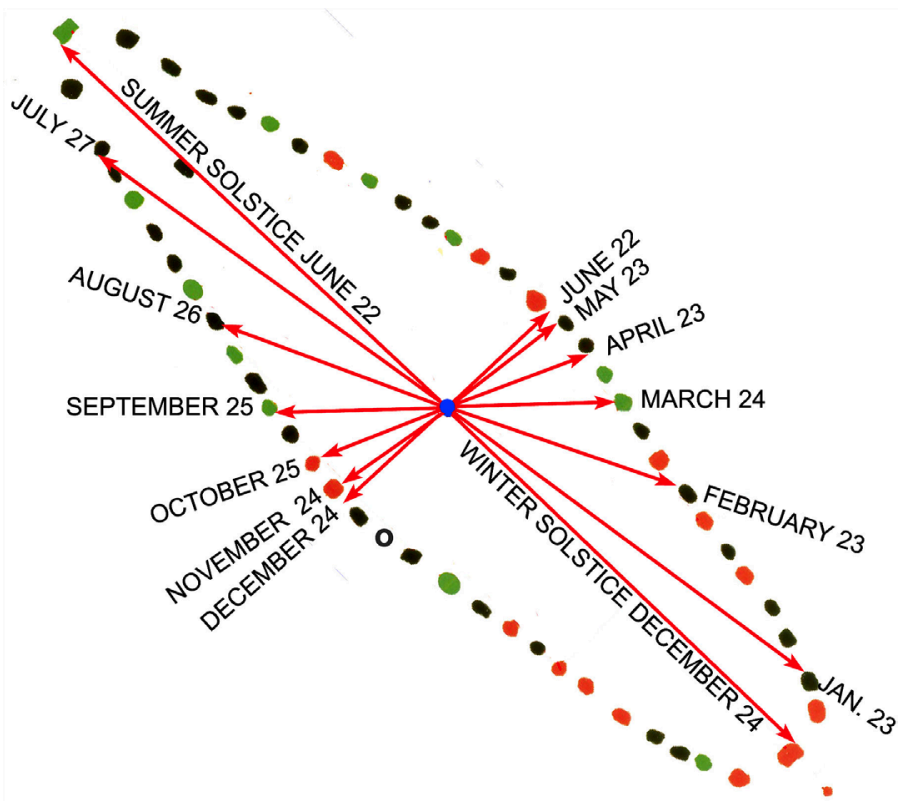

Figure 26. The monthly sunrise (the SE-sector) and sunset (the NW-sector) positions with respect to the individual stones. All months consist of 30 days except for July which includes 35 days giving a full year of 365 days.

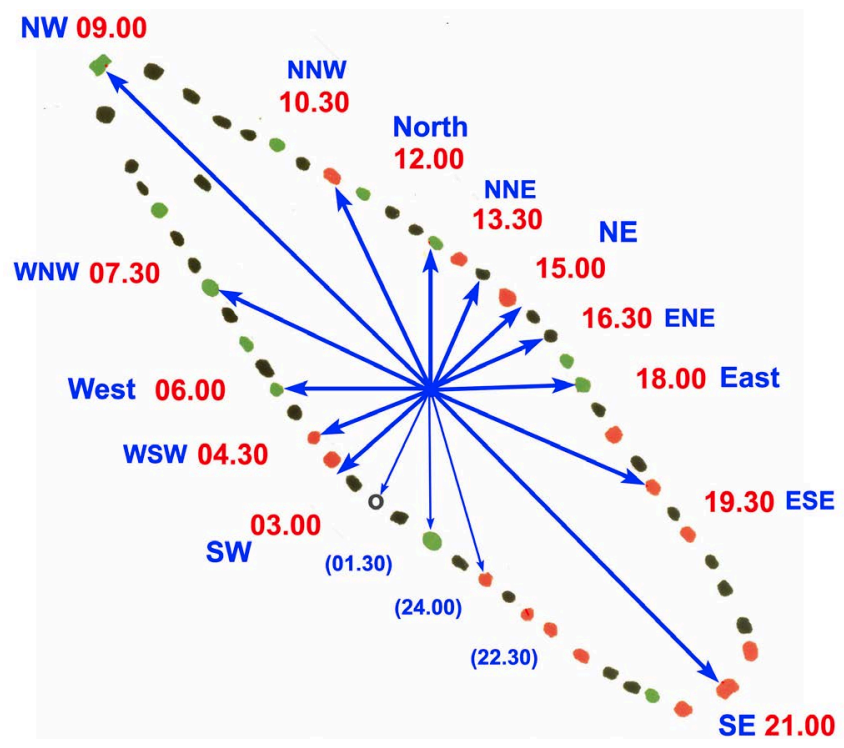

Figure 27. Ales Stones as a large sundial. With a tall rod in the centrum (inclined at $\sim 25^{\circ}$ to the north) the shadow will move as shown by the blue arrows with the hourly time in front. The day is composed of 16 segments each with a duration of 1 hour and $30 \mathrm{mi}$ nutes.

- On stone 8 in the NNW at 10.30 o'clock.

- On stone 12 in the $\mathrm{N}$ at 12.00 o'clock (noontime).

- On stone 14 in the NNE at 13.30 o'clock.

- On stone 16 in the NE at 15.00 o'clock (sunset at Winter solstice).

- On stone 14 in the ENE at 16.30 o'clock.

- On stone 12 in the E at 18.00 o'clock (sunset at Equinoxes). 
- On stone 8 in the ESE at 19.30 o'clock.

- On stone 1 in the SE at 21.00 o'clock (sunset at Summer solstice).

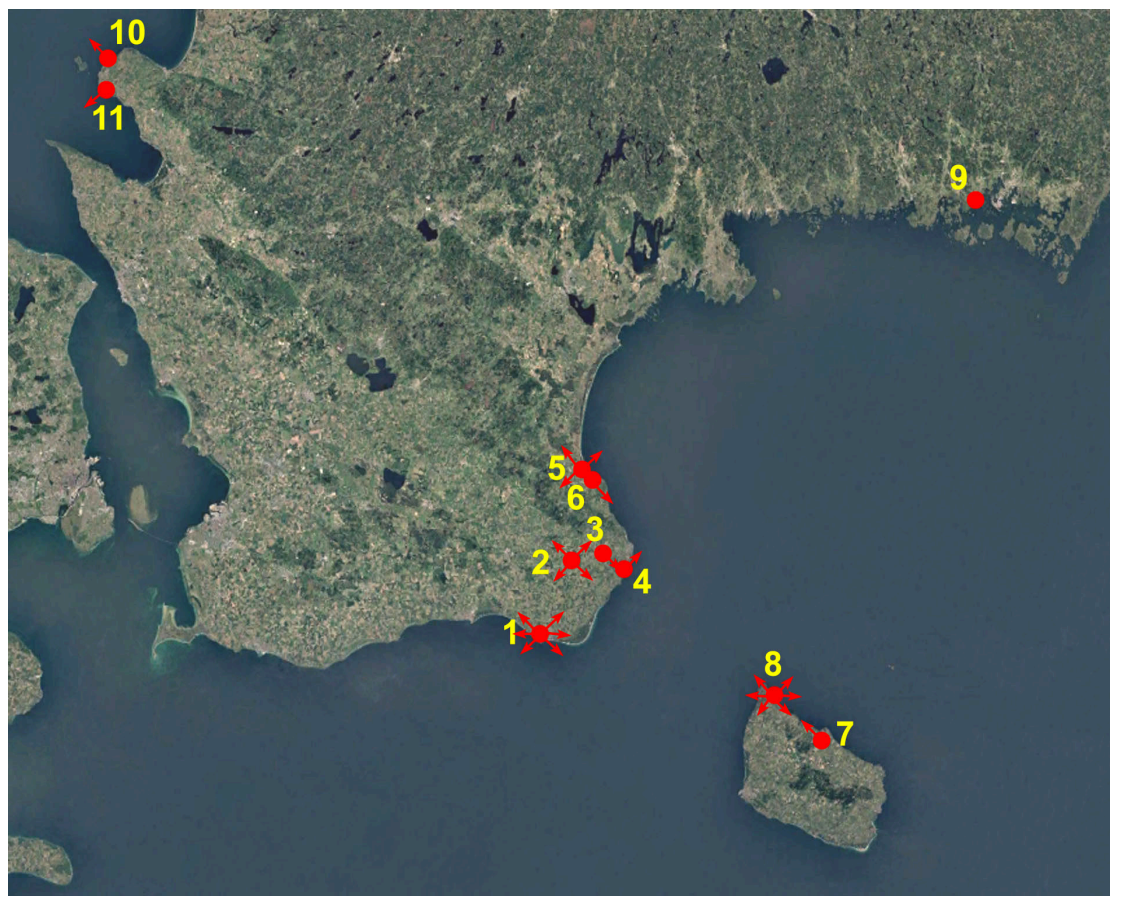

Figure 28. Some Bronze Age sites of solar alignments (illustrated by red arrows) in southern Sweden and the Island of Bornholm: (1) Ales Stones, (2) Stenhed, (3) Järrestad, (4) Brantevik, (5) Heimdall's Stones, (6) the Kivik grave, (7) Lensbjer, (8) Madsebakke, (9) the Golden Sky Dome from Mjövik, (10) Gröthögarna, (11) Dagshög.

In conclusion, the stone ship of Ales Stones records the 4 main solstice positions (Figure 25), the 12 monthly positions with a full year of 365 days (Figure 26), and 16 daily sundial positions with 1.5 hour's intervals (Figure 27). This provides full evidence of a sophisticated insight into astronomy of the Bronze Age people (Lind \& Mörner, 2010; Mörner \& Lind, 2013, 2018; Mörner, 2015; Mörner et al., 2018). There is no mathematical possibility what so ever that all these perfect alignments could have been obtained just by chance.

Furthermore, solar symbols and solar alignments are recorded at several other sites in southern Sweden (Figure 28). Obviously, there are numerous archaeological objects in southern Sweden that are constructed with solar alignment (e.g. Mörner, 2015). We will select a few sites for special analysis below. From the Island of Bornholm, we add two exceptionally interesting and important sites, especially site 8 with the "Madsebakke Sun-wheep" of almost identical astronomical calendar functions as those in Ales Stones.

\subsection{The Stone Ship at Stenhed}

Stenhed is another stone ship, $50 \mathrm{~m}$ long and $14 \mathrm{~m}$ wide and consisting of 30 blocks. Its long-axis is in the NW-SE. The annual Sun motions are record in steps of 11 months of 30 days and one month of 35 days (just as in Ales Stones; 
Figure 26). The Sun's daily movements record sixteen 1.5 hours segments (just as in Ales Stones; Figure 27).

Stenhed has an interesting geographic position right in the middle between Ales Stones and the remarkable Kivik grave (Lind \& Mörner, 2010; Mörner \& Lind, 2013).

\subsection{The Winter Solstice Festival at Järrestad}

Järrestad refers to a site of extensive rock-carvings west of Simrishamn (Althin, 1945; Lind \& Mörner, 2010: p. 86). Mörner (2012a) showed that most of the images exhibit strict solar alignments. A central figure is "the Dancer". She is oriented strictly facing the SE; i.e. the alignment of the sunrise at Winter solstice (Figure 29). There are 69 feet and 11 pair of feet carved into the bedrock: 75\% of those point to the sunrise at Winter solstice. There are also 19 pairs of shoes and 45 single shoes carved into the bedrock; $95.3 \%$ of them point to the sunrise at Winter solstice.

Obviously, "the return of light" at Winter solstice was a key event for the people living in southern Sweden in the Bronze Age. The Järrestad rock-carvings show an important manifestation of this: "the Dancer" faces the sunrise and $84 \%$ of all 144 feet and shoes are watching the event in the same alignment (Figure 29).

There is also a mini-ship oriented just as Ales Stones (Lind \& Mörner, 2010: p. 88; Mörner, 2012a). Many of the rock-carving pictures are fractured by a post-carving earthquake (Mörner, 2012b, 2014).

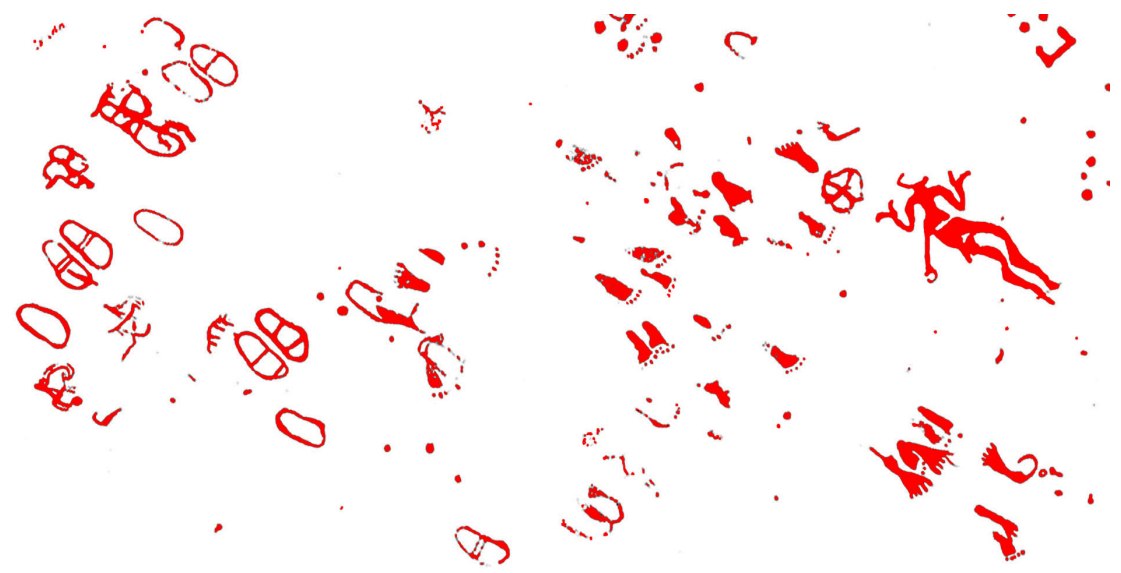

Figure 29. Part of the Järrestad rock-carving site (Mörner, 2012a). All the pictures (shoes, feet, sun wheal and the Dancer) are aligned with respect to the sunrise at Winter solstice in the SE. This was the Mid-Winter Festival and "the return of the Sun".

\subsection{Solar Alignment at Heimdall's Stones}

Heimdall's Stones refer to a $30 \mathrm{~m}$ wide circular astronomical calendar (Mörner et al., 2009). There are numerous rock-carvings in the stones; cup marks, an omega sign, a delta sign, sun symbols, etc. The ground surface of the monument is covered by eolian sand from the sand drift dated 600-500 BC; hence the mo- 
nument must be older than $600 \mathrm{BC}$.

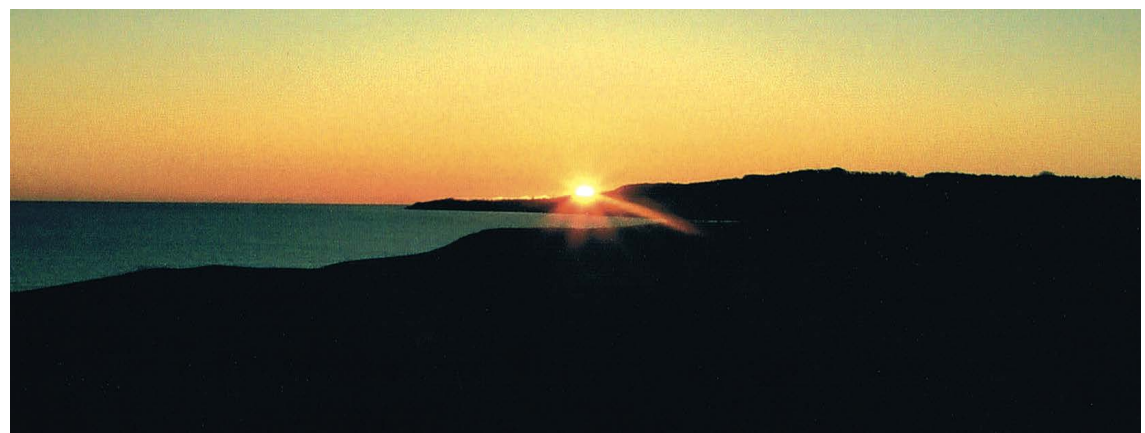

Figure 30. At Winter solstice, the Sun rises right in the notch in the slope of Stenshuvud when viewed from the centre of Heimdall's Stones over the block in the SE (from Mörner et al., 2009). In 4 minutes, the Sun will be at the peak of Stenshuvud. From Bornholm 70 $\mathrm{km}$ on the other side, there is an opposed sightline of the sunset at Summer solstice (Kaul, 2005).

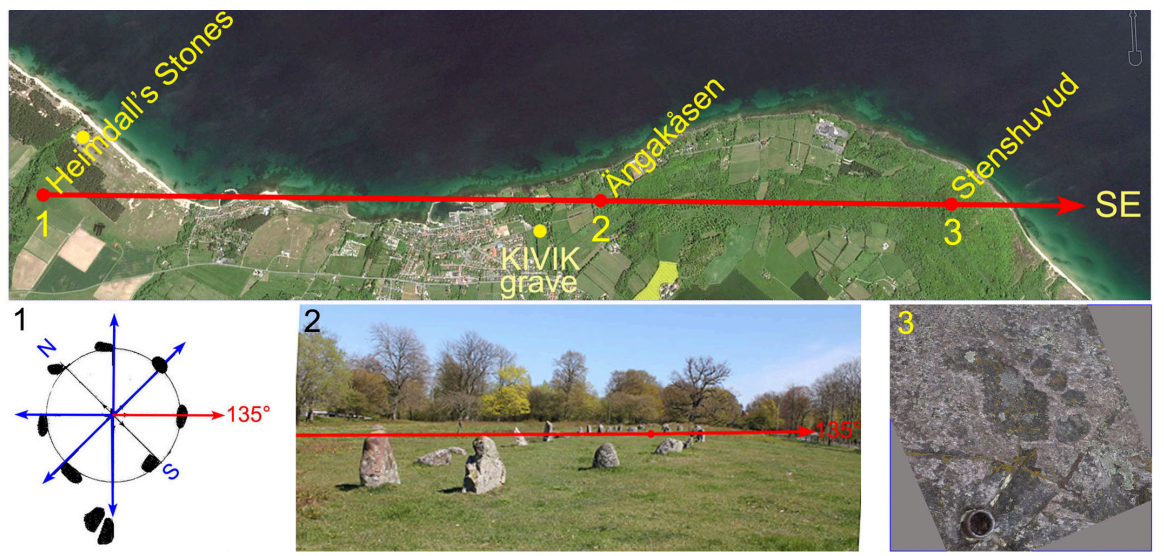

Figure 31. The sightline from Heimdall's Stones (1) via the Ängakåsen stone ship (2) to the peak of Stenshuvud (3) where there is a benchmark (+97 $\mathrm{m})$ and a rock carving of a foot. At Winter solstice, the Sun rises in the SE right along this line (Mörner et al., 2009).

The Heimdall's Stones monument includes sightlines of the sunrise and sunset at Winter solstice, of the sunrise and sunset at the Equinoxes and of the sunrise and sunset at Summer solstice (Mörner et al., 2009, Figures 1-3). Most important is the alignment of the sunrise at Winter solstice, which passes directly over the hillside of Stenshuvud (Figure 30). Figure 31 gives the sightline of the sunrise at Winter solstice from the archaeo-astronomical observatory of Heimdall's Stones (1) straight over the Ängakåsen stone ship (2) to the top of Stenshuvud (3) where there is a rock-carving of the front part of a foot pointing to the SE (just as the majority of feet and shoes at Järrestad; Figure 29). From the Island of Bornholm there is an opposed sightline to Stenshuvudon the sunset at Summer solstice (Figure 32; cf. Kaul, 2005; Mörner et al., 2009).

The Kivik grave indicates close contacts with the cultures in the East Mediterranean. The area may even have worked as a trading center from the onset of the Scandinavian Bronze Age at about 1750 BC (Lind \& Mörner, 2010; Mörner \& 
Lind, 2013, 2015).

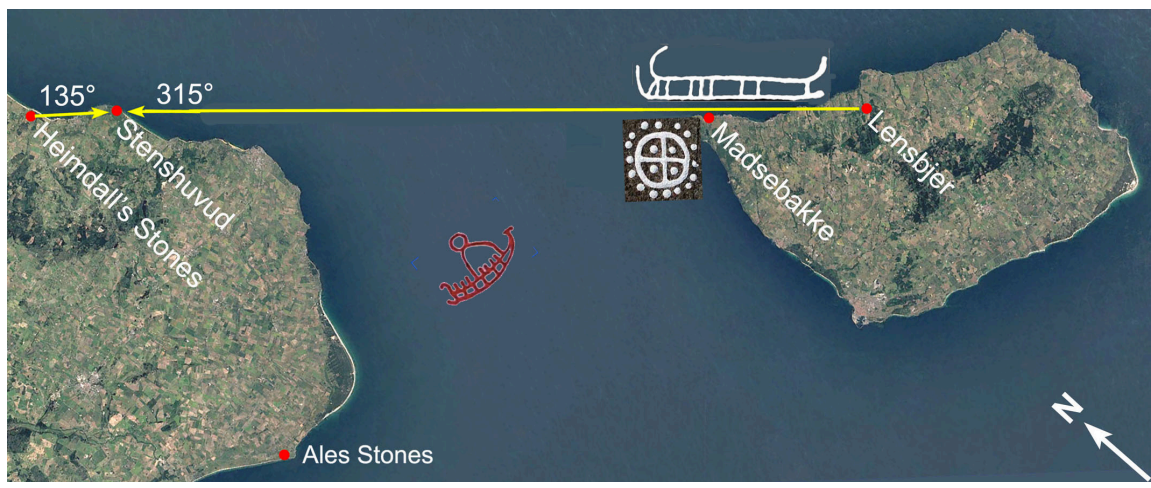

Figure 32. The sightline from Lensbjer to the sunset at Summer solstice over Hammer Odde and Stenshuvud in the NW (i.e. the opposed direction to that documented in Figure 31). The ship (white) has a form dating from 900-1000 BC. It sails towards the sunset. At Madsebakke (Allinge) there is a sun-wheel with the same astronomical function as that of Ales Stones. A ship (red) comes from the west; i.e. from the Ales Stones-Brantevik area in Sweden. This ship has a form dating from around $700 \mathrm{BC}$ (just the age of Ales Stones).

\subsection{Solar Alignment from the Island of Bornholm}

More than 100 rock-carving images are documented on the Island of Bornholm (Kaul, 1998, 2005, 2006). The boat images are dated at about 900-500 BC (Kaul, 2006; Cole, 2011). They exhibit close similarity to the boat images in the Simrishamn area indicating communications and cultural linkage (Cole, 2011).

At Lensbjer (at Lensgård), $3 \mathrm{~km} \mathrm{SW}$ of Gudhjem, Kaul (2001, 2005, 2006) found a site with six ships. Two of the ships points to the peak of Hammer Odde in the NW and further over the sea to Stenshuvud, and Kaul $(2005,2006)$ noted that the Sun sets along the same alignment at Summer solstice (Figure 32). The ship is $60 \mathrm{~cm}$ long. It is drawn with the bow in the direction to the sunset in the NW. Its shape suggests an age of 900-1000 BC (e.g. Cole, 2011).

At Madsebakke in Allinge on northwest Bornholm, there is a rock-carving with multiple images of shapes indicating ages ranging between 1000 and 500 BC (Kaul, 2005; Cole, 2011).
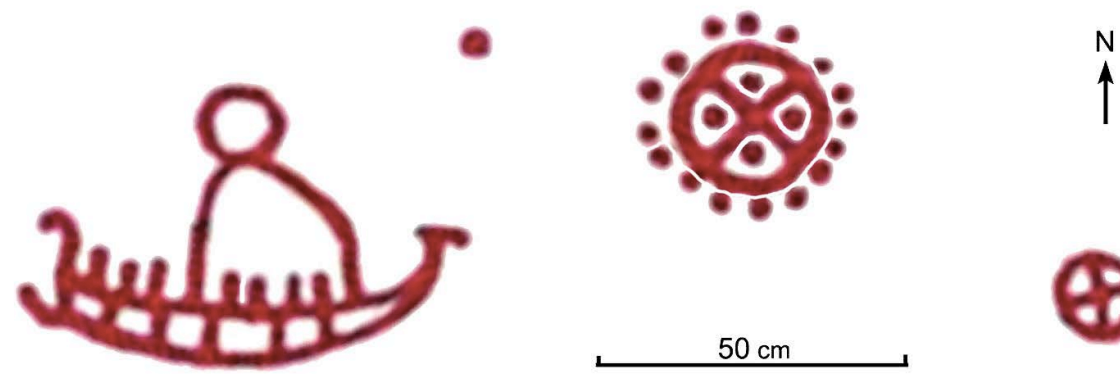

Figure 33. Segment of the Madsebakke rock-carving showing a ship of 700 BC characteristics sailing from the west to the east, and a sun-wheel of a perfect compass design (Figure 34) implying that it may have been used as a sundial and annual calendar. 


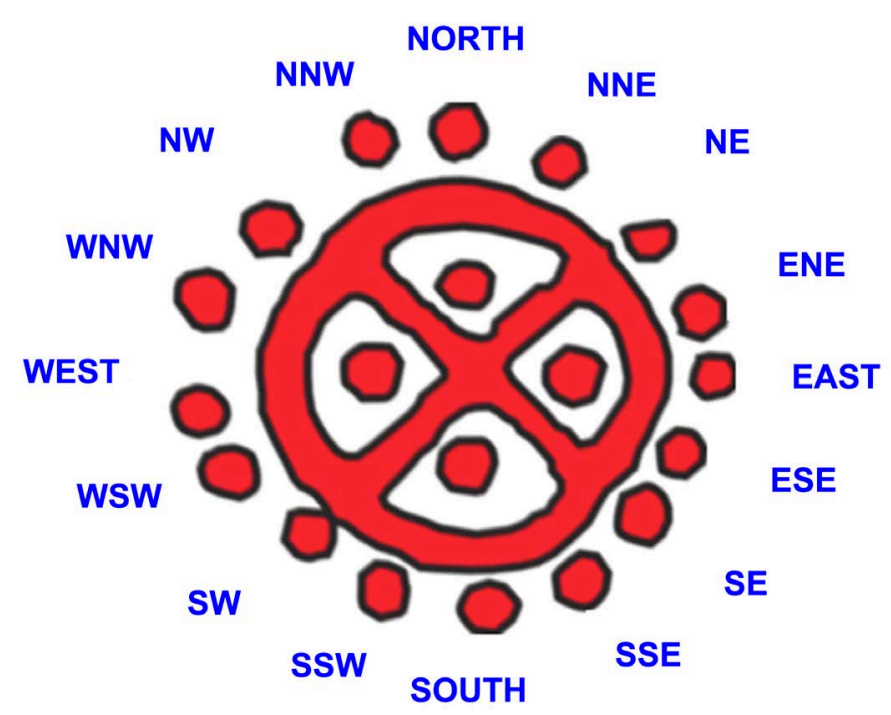

Figure 34.The Madsebakke sun-wheel has a design revealing a basic function as a compass implying that it can be used to document the daily and the annual motions of the Sun over the sky. This indicates very close, not to say identical, functions as the astronomical functions of the Ales Stones monument (Figures 24-27).

\subsection{The "Madsebakke Sun-Wheel" on the Island of Bornholm}

The Madsebakke rock-carving site includes the image of a sun-wheel: a sun-wheel divided in four segments and surrounded by 16 cup marks (Figure 33). We have undertaken a close field documentation of the exact geographic orientation of the sun-wheel (Figure 34). At Spring Equinox (March 21, 2019), we also documented the sunrise and sunset with respect to the sun-wheel, indicating perfect East/West alignments (Figure 35).

This enables us now to claim that the sun-wheel must have worked both as a sundial and as a compass or solar calendar (Figure 34). This implies an almost identical astronomical set-up and function as those documented in Ales Stones (Figures 24-27). The ship close by (Figure 33) has a form dating the rock-carving to 700 BC (Cole, 2011), i.e. the same age as Ales Stones.

The set-up as a sundial is illustrated in Figure 36 (left image): 16 segments each of which corresponds to 1 hour and 30 minutes (some irregularities are noted in the figure). The set-up as an astronomical calendar is illustrated in Figure 36 (right image): the alignments to the four main solar turning points. The alignment to the sunrise and sunset at Spring Equinox are documented in Figure 35. On a whole, this indicates that the "Madsebakke Sun-wheel" has identical functions to those recorded in Ales Stones (Figure 27 and Figure 25). Judging from the design of the nearby ship (Figure 33), the age of the rock-carving seems to be about $700 \mathrm{BC}$ (Cole, 2011), indicating that it is contemporary with Ales Stones, too.

The Madsebakke Sun-wheel provides a remarkable and novel record of the close connections existing in the Late Bronze Age between the Island of Bornholm and the Ales Stones-Järrestad-Brantevik-Kivik area in SE Sweden. 


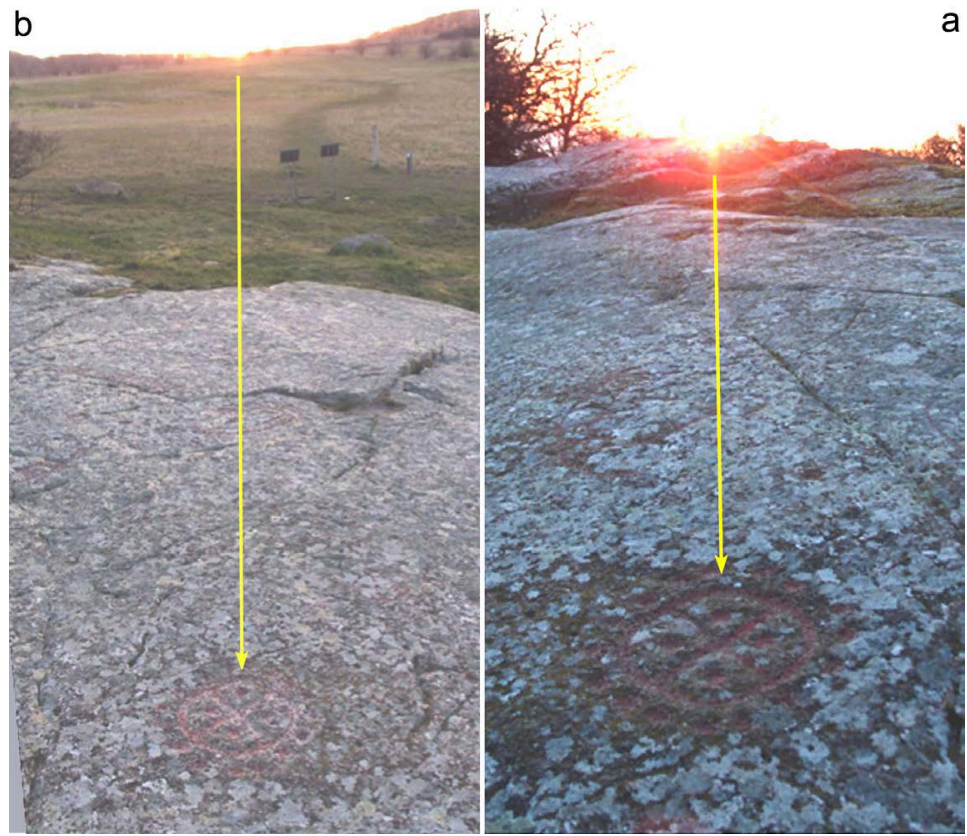

Figure 35. Documentation of the solar alignments at Spring Equinox (March 21, 2019) to the sunrise in the East (a) and the sunset in the West (b). Yellow arrows indicate the sunlight in relation to the sun-wheel; (a) the first light at sunrise and (b) the last light at sunset.
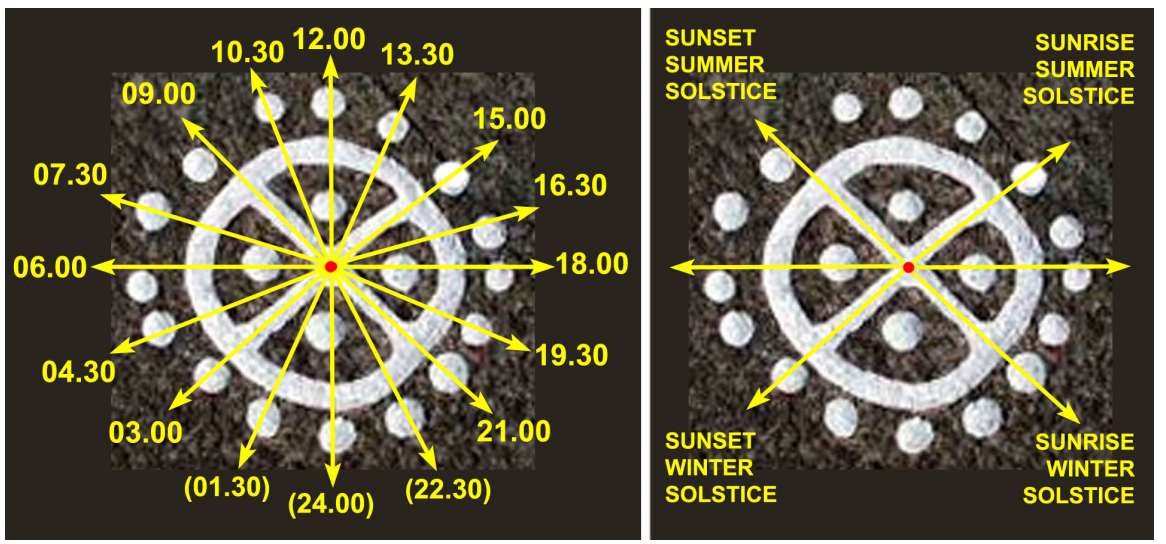

Figure 36. The Madsebakke sun-wheel with interpretations as a sundial (left) and as a compass with an annual calendar function (right). This implies very close, not to say identical, functions as the Ales Stones astronomical functions (Figures 24-27).

\subsection{Some Other Sites of Sun Cult Relevance in Southern Sweden}

We have addressed the questions of long-distance travel and trading (Lind \& Mörner, 2010; Mörner \& Lind, 2010, 2013, 2015) and the advanced astronomy and sun cult in the Bronze Age (Lind \& Mörner, 2010; Mörner, 2015; Mörner \& Lind, 2018). In this section, we will highlight a few facts of the Sun Cult flourishing in Southern Scandinavia in the Bronze Age (e.g. Montelius, 1911; Almgren, 1927; Bröndsted, 1938; Kristensen, 2010; Mörner \& Lind, 2018) with respect to some other sites in Southern Sweden (Figure 28).

The Kivik grave (site 6 in Figure 28) is a remarkable place as noted above 
(Figure 31). It has been further discussed in Lind \& Mörner (2010) and Mörner \& Lind $(2013,2015)$ and exhibits obvious links with the cultures of the East Mediterranean.

At Mjövik (site 9 in Figure 28) a golden urn was found in 1847. In 2017, we turned it up-side-down and found that we, in fact, were dealing with "sky dome" with 12 sun symbols, 12 moons and a 6-spoke sexagesimal system (Mörner \& Lind, 2018; Mörner et al., 2018). This bears testimony of an advanced and widespread Sun Cult during the Bronze Age.

The Bjäre Peninsula has numerous mounds from the Bronze Age and some sites with clear solar alignment (Mörner, 2015, Figure 19). We will here limit the discussion to two sites with clear solar alignments (sites 10 and 11 in Figure 28).

At Gråthögarna (site 10) there is man-made "road" leading out to a group of 8 stone mounds from the Bronze Age (Figure 37). At Summer solstice, the Sun sets right over one mound in the straight elongation of the "road" (Figure 38).

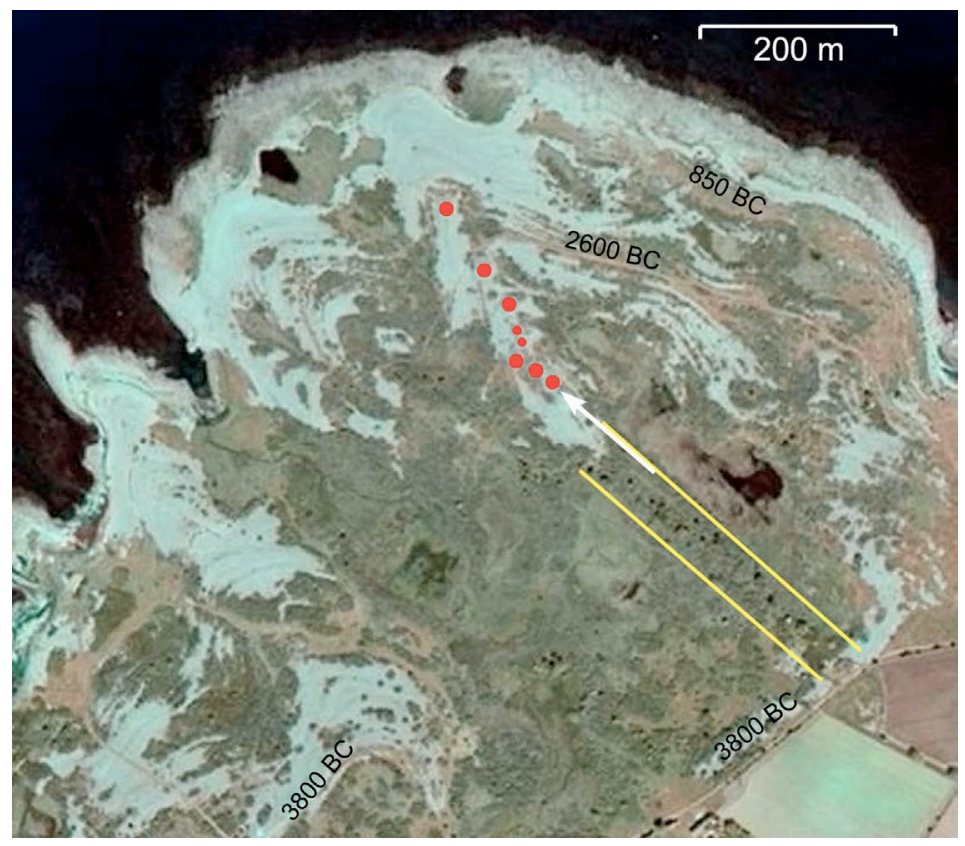

Figure 37. The Gråthögarna shore site. Yellow lines mark man-made "road" out to the field of 8 stone mounds from the Bronze Age. The sea levels of 3800, 2600 and $850 \mathrm{cal}$. yrs $\mathrm{BC}$ are marked. White arrow shows the sightline of Figure 38 of the sunset at the Summer solstice.

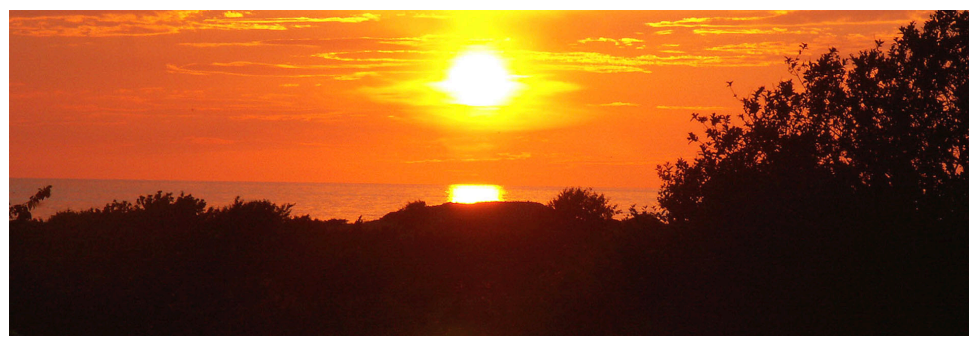

Figure 38. The sunset at Summer solstice right over one of the grave mounds in the same alignment as the man-made "road" shown in Figure 37. 
Dagshög (site 11) is a $35 \mathrm{~m}$ wide grave mound from the Bronze Age. The mound lies between two lines set by large stones: one in the NE-SW and one in WNW-ESE (Figure 39). At Winter solstice, Sun sets right along the line pointing to the tip of the Kullen Peninsula $14 \mathrm{~km}$ to the SW (Figure 40). The other line points to the sunset at about August 26 in the WNW, probably marking an important time of the year like harvest time.

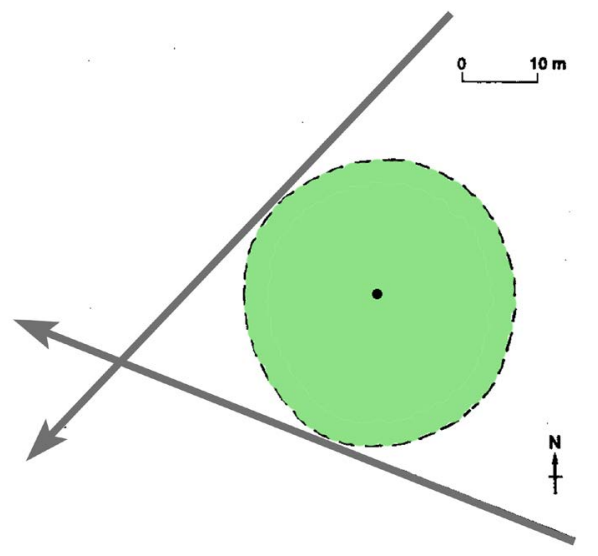

Figure 39. The Daghög grave (green) and stone-set lines (arrows).

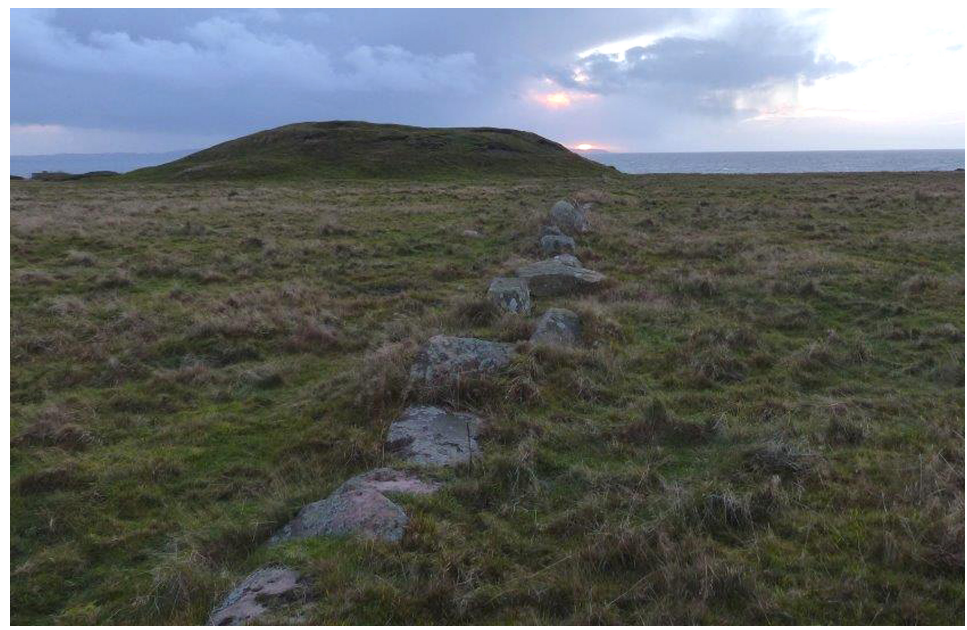

Figure 40. The sunset at Winter solstice along the stone-set line NW of Dagshög pointing right at the tip of the Kullen Peninsula in the SW.

\section{Conclusions}

After this long review of Ales Stones and related documents on an advanced Sun Cult and deep knowledge of astronomy during the Bronze Age, we limit our conclusions to the following main points.

1) Ales Stones was built at about $750-700$ BC. This is indicated by multiple criteria:

- Today, the sunrise at Winter solstice occurs $15-17 \mathrm{~cm}$ to the left of the stern stone. The deviation from a perfect alignment is due to astronomical variables (precession and tilt). In Figure 6, we have compensated for those va- 
riables, providing a perfect fit at $700 \mathrm{BC}$. This lends very strong support to an age of construction of $700 \mathrm{BC}$.

- Stratigraphic facts indicate that the ship was built shortly before the general sand drift dated at 600-500 BC (Figure 14, Figure 17).

- Stratigraphy also shows that the monument is likely to have been constructed shortly after the earthquake occurring at about 780-750 BC (Figure 17).

- The quarrying of the 4 quartzite blocks in Ales Stones (like the block used in the Brantarör grave) must have occurred shortly after the earthquake dated at 780-750 BC and fracturing the bedrock (Figure 18, Figure 19).

- The shipping from the natural harbour at Brantevik to the coast at Kåseberga (just downhill of Ales Stones), is likely to have occurred at around 750 BC when sea level was still high and the harbour conditions favorable (Figure 21, Figure 23).

- All available facts taken together seem to give converging indications of an age of the erection of Ales Stones of 750-700 BC.

- The solar alignment between Heimdall's Stones and the mountain peak of Stenshuvud, and the opposed alignment between the direction of rock-carved ships at Lensbjer and Stenshuvud indicate a cultural connection (Figure 32). Close cultural connection is also indicated by the design of the ships found in rock-carvings on Bornholm and in the Simrishamn area. The Bornholm carvings are assigned an age of 900-500 BC (Kaul, 2006; Cole, 2011) in full agreement with our findings of high Sun Cult activity at Ales Stones and in Österlen in general.

- The Madsebakke Sun-wheel provides remarkable functional and temporal similarities with Ales Stones, and the other monuments and rock-carvings in southeastern Sweden (Figure 28).

2) Ales stones were built as a sophisticated astronomical calendar:

- The long-axis of the ship and the position of the individual stones are built with strict alignment to the solar movements over the sky during the year and throughout the day (Figure 24).

- The 4 main directions at Summer and Winter solstices are also recorded by the cup mark figures on the top of stones 8 in the SE and NW (Figure 25).

- The monthly sunrises from December to June move from stone to stone with an interval of 30 days. The monthly sunsets from June to December also move from stone to stone with an interval of 35 days for the first month and 30 days for the remaining 5 months. This gives a full year of 365 days (Figure 26).

- The ship also works as a huge sundial of 16 segments each covering 1 hour and 30 minutes (Figure 27).

- This implies overwhelming facts that the Ales Stones monument was built as astronomical calendar of remarkable skill and practical dimensions.

- This builds on to previous knowledge of an intensive Sun Cult in southern Scandinavia during the Bronze Age (e.g. Montelius, 1911; Almgren, 1927; Bröndsted, 1938; Kristensen, 2010; Lind \& Mörner, 2010; Mörner \& Lind, 
2018).

- The Madsebakke Sun-wheel exhibits sophisticated astronomical functions almost identical to those recorded in Ales Stones.

3) Märta Strömberg (1997) described her project at Ales Stones in terms of three questions to be addressed: a) when was it built, b) what was the purpose, and c) what happened after. I think we have answered all three questions:

- It was built 750-700 BC as indicated by overwhelming facts highlighted in the text and summarized above under point 1.

- The purpose was the establishment of a sophisticated astronomical calendar giving the main solar turning points, the 12 months, the 365 days and the daily hours.

- Only limited activity can be recorded for the period $500 \mathrm{BC}$ to $800 \mathrm{AD}$. In the Viking time there must have been intense activity, however, judging from the mound found in the shore section (Mörner, 2011, 2015), which is full of bones and burned stones and dated at $995 \pm 45$ cal. yrs BP.

4) Finally, we stress the remarkable functional and temporal correlations here established between Ales Stones and the Madsebakke Sun-wheel.

\section{Acknowledgements}

We acknowledge the kind recalculation by Göran Henriksson (Associate Professor in Astronomy at Uppsala University) of the true timing of sunrise at Winter solstice with respect to the stern stone of Ales Stones (Figure 6). We are indebted to Ingvar Kullberg, who assisted us in the field, made independent measurements and took excellent photographs for us (Figure 35), to Conny Klang, who assisted us in communications and various practical matters, to archaeologists Hans Ekerow and Esbjörn Jonson, who took part in the excavations in 2011 and correct presentation of Ales Stones at site, to Marie Schram, Lind's field assistant for many years, and to Pamela Matlack-Klein for her kind linguistic check. All our C14-dates (21 by now) were done by Göran Possnert at the Uppsala C14-laboratory. As a curiosity, we note that it was Nils Lind (a close ancestor to one of us), who discovered the Madsebakke rock-carvings in 1884 . Finally we acknowledge a kind, sharp and very useful anonymous review.

\section{Conflicts of Interest}

The authors declare no conflicts of interest regarding the publication of this paper.

\section{References}

Alfredson, H., \& Meurling, K. (1976). Bästa vägen till Muckle Flugga: Notiser kring en resa till Island, Färöarna, Orkney och Shetland (192 p.). Stockholm: Wahlström \& Widstrand.

Almgren, O. (1927). Hällristningar och kultbruk. Kungl. Vitterhets Hist. Antikv. Akad. Handlingar, 35, 23-31.

Althin, C. A. (1945). Studium zu Bronzezeitlichen Felszeichnungen. Gleerups. 
Andersson, M., Knarrström, A., Söderberg, B., \& Wallebom, B. (2013). Ales stenar i nytt ljus (p. 80). Swedish Nat. Heritage Board, UV Rapport 2013.

Bergström, J., Daniel, E., Herner, E., Kornfält, K.-E., \& Wikman, H. (1988). Ales stenar stenarnas historia. Ale, 4, 1-13.

Bröndsted, J. (1938). Bronzealderens soldyrkelse. København: Gyldendal.

Carter, J. J., \& Malmström, V. J. (1979). Stenålderskalendrar i Sverige? Forskning och Framsteg, 5, 1-5.

Cole, A. J. (2011). A Social Semiotic Foray of Boat Images in Rock Art: Communication between Two Local Scandinavian Communities. In XXIV Valcamonica Symposium: Art and Communication in Pre-Literate Societies (pp. 130-136). Milano: Jaca Book.

Duczko, W. (2011). Utanför skeppet. Rapport från arkeologisk undersökning inom fornlämningsområde Ales stenar, Skåne, Sverige.

Hilfeling, C. G. G. (1777). Skånska teckningar. Köpenhamn.

Kaul, F. (1998). Ships on Bronzes: A Study in Bronze Age Religion and Iconography. Copenhagen: Danish National Museum.

Kaul, F. (2001). Flere nye hellristningsfund. Adoranten.

Kaul, F. (2005). Hellristninger. Bilder fra Bornholms Bronzealder. Rönne: Bornholms Museum.

Kaul, F. (2006). Udgravninger vid hellristninger (pp. 28-49, 50-63). Adoranten.

Kristensen, K. (2010). Rock-Art and Religion: The Sun Journey in Indo-European Mythology and Bronze Age Rock Art. In A. F. F. Criado Boado (Ed.), From Representation and Communication: Creating an Archaeological Matrix of Late Prehistoric Rock Art (pp. 93-115). Oxford: Oxbow.

Lind, B. G. (2004). Ales stenar ur ett arkeoastronomiskt perspektiv. Malmö: Stjärnljusets Förlag.

Lind, B. G. (2005). Ales stenar som sol kalender. Ale, 3, 27-33.

Lind, B. G. (2011). Från Brantarör till Brantevik. Malmö: Stjärnljustets Förlag.

Lind, B. G. (2017). Ales Stenar: Dateringen (16 p.). Malmö: Stjärnljusets Förlag.

Lind, B. G. (2018). Ales Stenar: Restaureringen 1916 (16 p.). Malmö: Stjärnljusets Förlag.

Lind, B. G., \& Mörner, N.-A. (2010). Mykenska och Feniciska spår på Österlen. Malmö: Stjärnljusets Förlag.

Lind, G. (1977). Har skeppssättningen haft en astronomisk funktion? Elementa, 60, 76-77.

Montelius, O. (1911). Solguden och hans dyrkan. Nord. Tidskrift.

Mörner, N.-A. (2011). Rapport över sommarens arkeologiska utgrävningar vid Ales Stenar. Del 2: Geologiska Arbeten. Rapport till RÄ̈ Länsstyrelsen i Skåne (24 p.).

Mörner, N.-A. (2012a). Strict Solar Alignment of Bronze Age Rock Carvings in SW Sweden. Journal of Archaeological Science, 39, 3301-3305. https://doi.org/10.1016/j.jas.2012.05.027

Mörner, N.-A. (2012b). Paleoseismic Fracturing of Rock Carvings 1000 BC in SE Sweden. In Paleoseismology \& Archaeoseismology (pp. 127-130). Morelia: Paleoseismology \& Archaeoseismology.

Mörner, N.-A. (2014). An M > 6 Earthquake 750 BC in SE Sweden. Open Journal of Earthquake Research, 3, 66-81. https://doi.org/10.4236/ojer.2014.32008

Mörner, N.-A. (2015). Ales Stones in SE Sweden: A Solar Calendar from the Late Bronze Age. Journal of Archaeological Science: Reports, 2, 437-448.

https://doi.org/10.1016/j.jasrep.2015.04.002 
Mörner, N.-A. (2017a). Ales Stenar: Stenbrottet (16 p.). Malmö: Stjärnljusets förlag.

Mörner, N.-A. (2017b). Comments on "New Light on Ale’s Stones” by B. Söderberg \& A Knarrström.

Mörner, N.-A., \& Lind, B. G. (2010). A Mediterranean Trading Centre in SE Sweden. In S. P. Paraminopolos (Ed.), The Atlantis Hypotesis-Commentary 2008 (pp. 685-699). Athens: Heliotopos Publications.

Mörner, N.-A., \& Lind, B. G. (2012). Stonehenge Has Got a Younger Sister. Ales Stones Decoded. International Journal of Astronomy and Astrophysics, 2, 23-27. https://doi.org/10.4236/ijaa.2012.21004

Mörner, N.-A., \& Lind, B. G. (2013). The Bronze Age in SE Sweden: Evidence of Long-Distance Travel and Advanced Sun Cult. Journal of Geography and Geology, 5, 78-91. https://doi.org/10.5539/jgg.v5n1p78

Mörner, N.-A., \& Lind, B. G. (2015). Long-Distance Travel and Trading in the Bronze Age. Archaeological Discovery, 3, 129-139. https://doi.org/10.4236/ad.2015.34012

Mörner, N.-A., \& Lind, B. G. (2018). Astronomy and Sun Cult in the Swedish Bronze Age. International Journal of Astronomy and Astrophysics, 8, 143-162. https://doi.org/10.4236/ijaa.2018.82010

Mörner, N.-A., Jonsson, E., Ekerow, H., Henriksson, G., \& Lind, B. G. (2012). Vi utvärderar och underkänner: RÄ̈ Rapport 2012:21 Ales Stenar: Fördjupat kunskapsunderlag författad av Bengt Söderberg, Annika Knarrström \& Kennet Stark. Skrivelse till Länsstyrelsens I Skåne Kulturmiljösektion och Riksantikvarieämbetet.

Mörner, N.-A., Lind, B. G., \& Henriksson, G. (2018). A Golden Calendar from the Bronze Age. Archaeological Discovery, 6, 53-61. https://doi.org/10.4236/ad.2018.62004

Mörner, N.-A., Lind, B. G., \& Possnert, G. (2009). Heimdall's Stones at Vitemölla in SE Sweden and the Chronology and Stratigraphy of the Surroundings. Geografiska Annaler, 91, 205-213. https://doi.org/10.1111/j.1468-0459.2009.00364.x

Roslund, C. (1979). Ale forntidsmatematiker och astronom (p. 5)? Forskning och Framsteg.

Söderberg, B., \& Knarrström, A. (2015). New Light on Ale’s Stones. Lund Archaeological Review, 21, 87-106.

Söderberg, B., Knarrström, A., \& Stark, K. (2012). Ales Stenar: Fördjupar kunskapsunderlag. RÄ̈ Rapport 2012:21.

Strömberg, M. (1990). Vikingamonument eller maktsymbol i bronsåldersbygd? Ystad: Ystads Fornminnesförening.

Strömberg, M. (1992). Fortsatta fältstudiervid Ales stenar. Österlen 1992: Årsbok från den samlade hembygdsrörelsen på Österlen, Simrishamn.

Strömberg, M. (1997). C14-dateringar vid Ales stenar. Ale, 1, 9-21. 


\section{Appendix}

In order not to "contaminate" our main paper with negative discussions of unfortunate misunderstandings with respect to Ales Stones, we put these perspectives under this separate additional note.

It all goes back to a very strange excavation in 1996. Strömberg intended to try to find datable material underneath one of the stones, in order to get a final date of the erection of the monument. She selected stone N24 (the $5^{\text {th }}$ stone on the northern side from the stern stone). She put two men to dig and sample any organic matter, but left for a private meeting (though this was her most important excavation). A pit was dug on the outer side of the stone, and when the men reached "the stone foot" (i.e. the circle of stones that had been hit into the bounder clay to keep the big block in position) they stopped at a depth of about $60-70 \mathrm{~cm}$. In the lowermost $10 \mathrm{~cm}$ they found some black lumps, which they put into a plastic bag and backfilled the pit. When Strömberg returned she got the sample bag. On the bag she wrote: "Ales stenar, beside block N24, ca $70 \mathrm{~cm}$ below surface, juni-96" (see, Mörner, 2015, Figure 16). A piece of charcoal of birch was C14-dated at $525 \pm 105$ cal. yrs AD (Strömberg, 1997; Mörner et al., 2012; Mörner, 2015).

Here started the controversy about the age and function of Ales Stones. Strömberg (1997) unfortunately wrote that the sample came from beneath Stone N24, adding: "if we can trust the excavators", which sounds like she was not sure herself.

We found the original sample bag, on which it is clearly written "beside ( $S_{w e-}$ dish: invid) block N24". "Beside" and "beneath" refer to two totally different positions. "Beside" the block implies that the erection of Ales Stones must be older than $525 \pm 105$ cal.yrs AD (our opinion: e.g. Lind \& Mörner, 2010; Mörner, 2015). "Beneath" the block implies that Ales Stones must be younger (Strömberg, 1997; Söderberg et al., 2012; Söderberg \& Knarrström, 2015).

The recovery of the original sample-bag (by Mörner on March 14,2012) was a great thing for us realizing that something was wrong because of the same age of the charcoal claimed to come from beneath the block and from the food remains from inside the urn (Figure 41). Photos of the text on the sample-bag were published (Mörner et al., 2012; Mörner, 2015; below Figure 41(C)). One of the men who actually undertook the excavation was interviewed. He was quite sure that they had dug down to the stone-foot some $60-70 \mathrm{~cm}$ below surface, retrieved the samples in the lower part of the section, backfilled the pit and handed over a plastic bag with the samples to Strömberg, when she returned (certainly they had never gone below the stone).

In this situation, we are convinced that there can only be one true story, and this must be that the dated sample came from beside the stone, not below the stone. Therefore, Ales Stones must be older-not younger-than the $500 \mathrm{AD}$ date.

Obviously, Strömberg (1997) herself was not sure. The more sure were her successors, however (Söderberg et al., 2012; Andersson et al., 2013; Söderberg \& Knarrström, 2015). In a special report (Mörner et al., 2012), we objected to the 
handling of the review of Ales Stenar by Söderberg et al. (2012). Mörner (2017b) objected to the story by Söderberg \& Knarrström (2015).
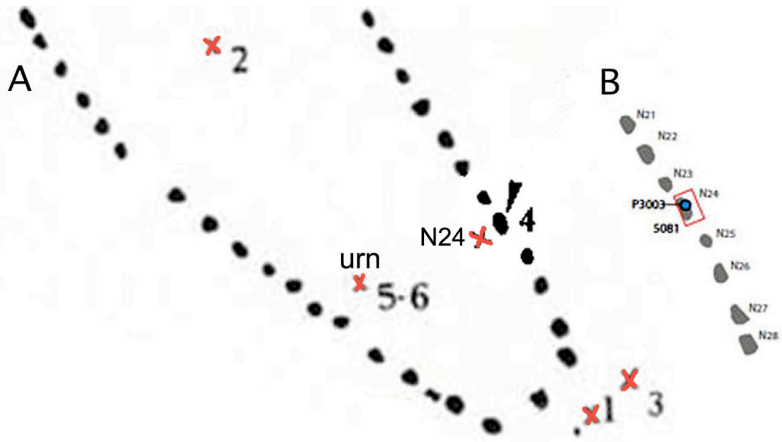

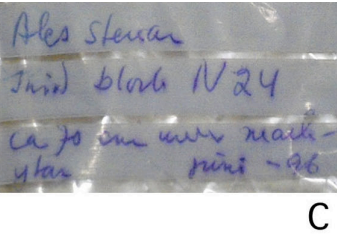

Figure 41. A: the original drawing by Strömberg (1997) with sites of C14-dates (1-6), the urn and excavation pit (4) beside block N24. B: the segment with the block N24 now with the sampling site wrongly sifted to a position below the block by Söderberg et al. (2012). C: photo of the original sampling-bag saying that the sample was taken beside (not below) bock N24 (from Mörner, 2015).

Besides the illusion of the correct position of the dated sample (beside not below block N24) just discussed, the proponents of a date of Ales Stones of about 500-1000 AD claim that the building of huge stone ships is typical for the Late Iron Age to Viking Age (Söderberg et al., 2012; Söderberg \& Knarrström, 2015). Lind (2017) replied to this that all the ships built in the Late Iron Age and Viking Age have smoothly curved sides and sharp bows and sterns (Figure 42) contrary to Ales Stones, which has a truncated stern and an extended keel with rams typical for Greece ships in the Bronze Age.

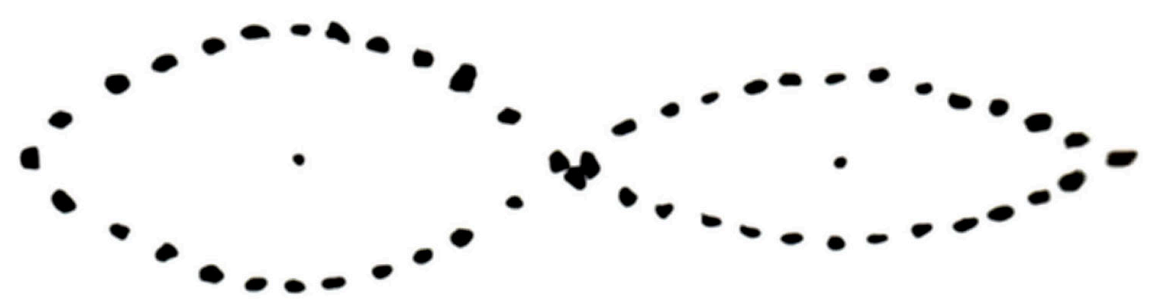

Figure 42.The Anund ships at Västerås from the Viking period. The sides are smoothly curved and the bow and stern are pointed (from Lind, 2017) contrary to the Ales Stones ship which has a truncated stern and a keel extended into rams, just as the Greece ships of the Bronze Age had.

In conclusion, there seems to be no valid argument for claiming that Ales Stones was built in the period 500-1000 AD. On the other hand, there seems to be overwhelming evidence of a Late Bronze Age time of the erection of the monument. 